\title{
Social effect of Covid-19: Estimates and alternatives for Latin America and the Caribbean
}

Ivonne Acevedo ${ }^{+}$, Francesca Castellani $^{*}$ Iván Flores ${ }^{+}$, Giulia Lotti* y Miguel Székely ${ }^{+}$
* $\quad{ }^{+}$Centro de Estudios Educativos y Sociales. *Inter-American Development Bank. The document does not reflect the views of the Inter-American Development Bank or its Board of Directors. We are thankful to the Inter-American Development Bank's Country and Regional Economists Group for their useful comments and suggestions. We are also grateful to the Editor of LAER and two anonymous reviewers for their comments.

\begin{abstract}
This document offers estimates of the possible changes in the social structure of the countries of Latin America derived from the consequent economic contraction from the Covid-19 pandemic, and explores the possible costs and benefits of different types of interventions to cushion its impact. The analysis forecasts that the number of people living in poverty (extreme and moderate) would increase by up to 44 thousand million people in the region. It also finds that the policy with the highest benefit-cost ratio is the postponement of payroll taxes and social security contributions. Other alternatives such as granting support to unemployed persons, temporarily doubling the benefits of existing social programs, and the transfer of income to self-employed workers also generate a favorable benefit-cost ratio, with differences among countries.
\end{abstract}

Keywords: Poverty, inequality, transfers.

JEL Classification: I31, I32, I38. 


\section{Introduction}

Since the end of February 2020, when the first case was reported in Brazil, Latin American and Caribbean (LAG) countries have adopted a wide range of policies to contain the spread of the coronavirus (Covid-19). Although in most cases a rapid response to the public health threat has been implemented with strict containment measures, the region continues its efforts to control the virus. In late May, the World Health Organization (WHO) declared Latin America the new "epicenter" of the Covid-19 pandemic, and by late September, Latin America had become the region with the highest mortality rates. ${ }^{1}$

The response to the health crisis has inevitably led to a drastic reduction in economic activity, which has become a challenge of similar dimensions to the health problem. According to projections by the International Monetary Fund (IMF, 2020), the effect on the Gross Domestic Product (GDP) may be a contraction of around $9 \%$ in the region as a whole, which leads to the prediction, on the one hand, of a generalized reduction in income, ${ }^{2}$ and on the other, to the exacerbation of previously existing social gaps in the absence of a consolidated social protection policy in most countries. Furthermore, as the emergency develops, it becomes evident that some types of lost jobs will not be able to be recovered while new skills needs will probably emerge in different sectors, which are not necessarily available.

In particular, one concern is that young people, women, people with disabilities, ethnic minorities and migrants are populations that tend to be more vulnerable to adverse impacts since even before the Covid they showed lower rates of labor participation and greater informality. ${ }^{3}$ Informality has many causes, from poor public services, to a heavy regulatory regime and low enforcement (Loayza, Servén and Sugawara, 2013), and is one of the great challenges in the region, as these types of activities usually generate less income, are generally seen as not paying taxes or social security contributions (Meghir, Narita and Robin, 2015) and are more susceptible to suffering a short-term economic slowdown since by their nature they do not have employment contracts or social benefits, such as sick leave or unemployment benefits (Goñi, López and Servén, 2011; Bosch and Esteban-Pretel, 2015). ${ }^{4}$

This document provides estimates on possible changes in the social structure of LAC countries resulting from the economic downturn, with the aim of "calibrating" different public policy responses to cushion them. Indeed, several countries have already put in place some bold support mechanisms towards households and enterprises to alleviate recessionary pressures and systemic risks, and which may have a significant favorable impact. Some of these measures include income transfers for the low-income population; temporary transfer programs for vulnerable groups and informal workers who did not receive cash transfers; initiatives to protect food security; temporary wage subsidies and unemployment insurance schemes for businesses to help avoid massive layoffs; and credit and liquidity guarantees for affected businesses to avoid bankruptcy (ECLAC, 2020a), among others. This study also explores the possible costs and benefits of some of these interventions, with the aim of identifying fiscally viable alternatives for the region.

The document has 5 sections. The first summarizes the most recent information on the social composition of the countries in the pre-Govid region. The second discusses the macro-

1 By mid-August, the region reported an average of more than 86,000 infections and 2,600 deaths per day, reaching 6,000,000 confirmed cases and 237,360 deaths.

2 Loayza (2020) predicts that under a pessimistic scenario, the world's poor could increase by 70\%; for the OECD (2020), the extreme poor in LAC could increase from 67.5 to 90 million; UNICEF (2020) highlights the risk in particular of increases in child poverty, which could rise by $22 \%$ in LAC.

3 Women are highly concentrated in occupations and sectors most affected by the crisis (hotel, food and retail trade, among others) (World Bank, 2020). Many women work in the health sector as doctors and nurses (Cruz Aguayo et al., 2019) and their health is at greater risk. In addition, they spend three times more time on unpaid domestic and care work (World Bank, 2020, ILO, 2020).

4 The link between informality and productivity or growth is less clear: on the one hand, it might lead to misallocation of resources and decrease productivity by allowing less productive jobs (informal) to exist, on the other hand it might be beneficial for growth as it can provide flexibility (Ulyssea, 2018). 
economic scenarios used in the estimates. The third section presents the main results regarding the expected impact of the economic contraction on poverty and on the extension of the middle classes. The fourth provides an overview of the costs and benefits of different public policy interventions to cushion the impact of the economic crisis, and the last section offers some conclusions.

\section{The starting point: poverty in Latin America and the Garibbean pre-Govid}

The emergence of Covid-19 found Latin America and the Caribbean (LAC) in a state of social and economic fragility, in contrast to the favorable environment that characterized the first decade of this century. On the economic front, several countries were experiencing growth rates below their potential in recent years, while others were gradually recovering with incipient macroeconomic stability. A common denominator in both cases has been the reduced fiscal space to reactivate the economic activity. Specifically, in the 2010-2019 period, the region's average growth rate declined from 6 to 0.2 percent per year, and central government public debt increased, on average, by 15 percentage points compared to 2011 (ECLAC, 2020a). In addition to macroeconomic weaknesses, social conflicts were observed in several countries in 2019 (World Bank, 2020), which from March 2020 were overlaid by the pandemic.

In terms of the social composition of the population, between 2000 and 2018, the percentage of the poor population was reduced on average by 20 points, which contributed to a significant expansion of the middle class. By 2019 on average, the poor (extreme and moderate) in LAC represented 23.8 percent of the population, the vulnerable middle-class 37.3 percent, and the consolidated middle-class 36.2 percent (statistics by country are presented in Figure 1). It should be noted that, in order to facilitate comparisons among countries in the region, the 2011 international poverty line of US $\$ 5$ per day PPP is used, which differs from the national poverty lines used by each country-which are constructed using other methodologies and parameters-so that it is not possible to make comparisons between international and national poverty lines.

\section{Scenarios}

Although the magnitude and duration of the current economic crisis are still uncertain, what happened in previous financial crises provides information for an initial assessment of the possible social effect that Covid-19 will have on the population's well-being. This study uses this information: (i) identifying the relationship (elasticity) between reductions in GDP and changes in wage income in some episode of past crisis; (ii) based on GDP projections already available for the year $2020,{ }^{5}$ the same ratio GDP/wages is used to forecast how wage income will contract in the current period; and (iii) using more recent household surveys for each country (see Table A.1 in the Annex), a (downward) adjustment factor is applied to individual incomes using the same ratio identified in (ii) to simulate the effect of the current crisis on available resources at the household level. ${ }^{6}$ Since household surveys from previous episodes allow for the identification

5 For the purposes of this study, we use the reports on the Latin American economy from FocusEconomics' LatinFocus Consensus Forecast, which provide consensus projections among analysts and financial institutions, updated month by month. The institutions consulted include Barclays Capital, BNP Paribas, Citigroup Global Markets, EIU, Fitch Solutions, JPMorgan, Moody's Analytics, and Oxford Economics, among others. However, it is important to note that the consensus projections may differ from other estimates -especially from the most recent projections that incorporate updated information on the performance of the economies. Thus, for this exercise, they are used to approximate the impact of the crisis on the distribution of social classes in various scenarios.

6 To estimate the impact on total income (labor and non-labor), the ratio of GDP to wages is taken as a reference, since wages generally represent around 50 percent of household income, and because wages are one of the main channels of transmission between changes at the macroeconomic level and people's well-being in the short and medium-term. The low variation of the relative importance of wage incomes as a share of total income can be corroborated from data from The Conference Board Total Economy Database ${ }^{\mathrm{TM}}$ (Adjusted version),July 2020 (https://www.conference-board.org/data/economydatabase/total-economy-database-productivity, Base:TED2) which shows that the Share of Total Labor Compensation in GDP in the countries we analyze (the data base does not include El Salvador, Panamá, Honduras only) in 2019 varied from $44.6 \%$ in Ecuador to $54.9 \%$ in Costa Rica (only Bolivia shows a smaller level of 41.5 ) with a standard deviation across countries of $14 \%$ in that year. Furthermore, the average standard deviation of the same ratio across countries over the lapse of the past 2 decades is of less than 3 percent (with a maximum of $8 \%$ for Bolivia). 
of how the historical reference crises affected different age groups, sex, ethnicity, education, urban/rural location, and sector of activity differently, for the estimates of post-Covid social impact for each country, the same disparities (relative impacts) are used to define a different "dose" of economic impact for each group. We acknowledge that the economic shock generated by the great confinement is different from past crises. At the same time, we are hoping that the different economic shock is well captured by the expected fall in GDP, whose magnitude is indeed larger than in other crises. We also recognize that the sectors hit will be different in this crisis, but overall, we expect the shock to affect similar vulnerable populations in terms of age, education, gender and ethnicity, as in previous downturns.

- Scenario A: takes as a reference the ratio of the yearly change in GDP/change in wages (i.e., the percentage change in real wages for each point of change in GDP) observed in some period of economic contraction prior to 2020 for each country - in several cases this episode is the international financial crisis of 2008-2009, but in others the relevant years are different (see Table A.2 in the annex). This rate is called the "elasticity" of wages to changes in GDP. The elasticity is in turn used to adjust income in the most recent household survey available for each country to obtain a post-economic impact income. Because information is available on differences between groups, the shock is applied differently, which is equivalent to simulating a post-Covid scenario of the same magnitude to the largest economic contraction in the recent past.

- Scenario B: the "elasticity" calculated for Scenario A is multiplied by the level of GDP expected to be observed in 2020 as a result of the pandemic, resulting in an expected rate of change in wages also for 2020. For this scenario, the so-called "consensus" estimate from FocusEconomics' LatinFocus Consensus Forecast is used as a prediction of change in GDP in 2020, which provides an average of the predictions of different analysts and financial institutions. This information is used to estimate the change in wage income that corresponds to the new macroeconomic scenario. As in scenario A, historical information on relative changes between groups is used to apply a differentiated effect in the face of different population characteristics.

- Scenario C: similar to scenario B, but instead of using a consensus macroeconomic scenario for each country, the most pessimistic projection of change in GDP in 2020 from FocusEconomics' LatinFocus Consensus Forecast is taken into account. This prediction provides the expected annual change in wage incomes and continues with the procedure described above.

$7 \quad$ The most pessimistic growth projections are used, which generally correspond to a percentage between the consensus level and the prediction made by the International Monetary Fund. In fact, when this study was initiated in April 2020, the available projections estimated a negative, but comparatively low economic effect of the pandemic. However, the scenarios published in the following weeks were continuously more pessimistic. We decided to use the most updated projections available in June (when finalizing the study), which also coincided with being the most negative among all the estimates so far. 
Figure 1. Distribution of the population by socioeconomic level, around 2019*

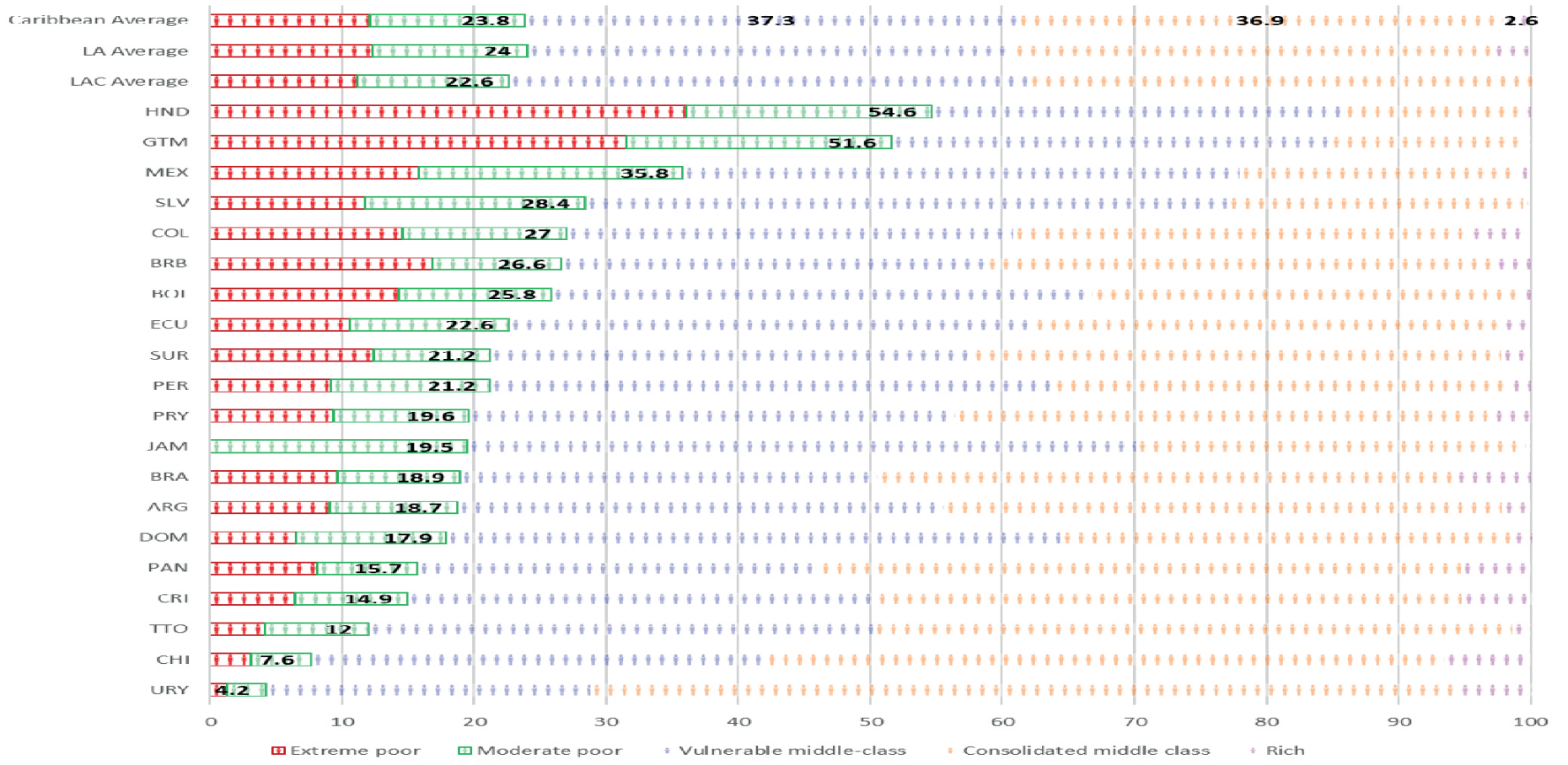

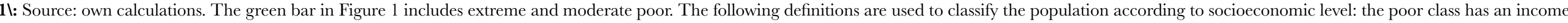

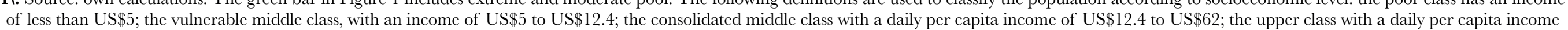

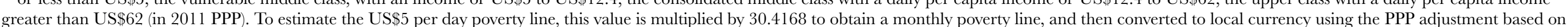

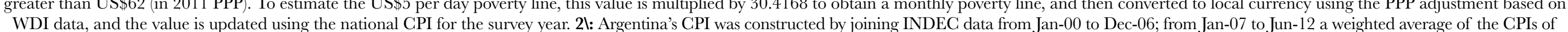

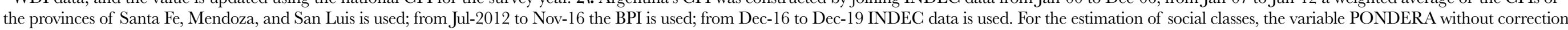

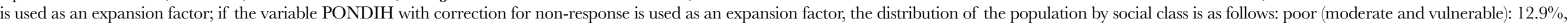



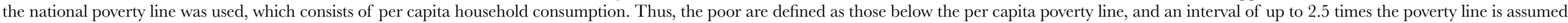

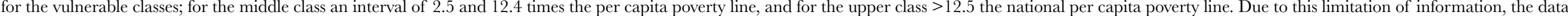

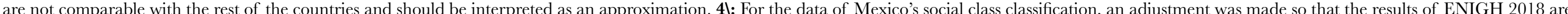

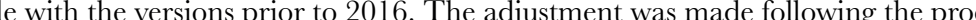

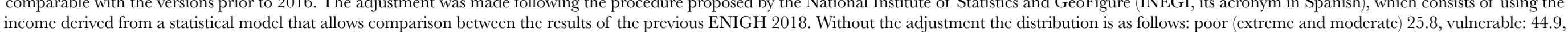
consolidated middle class: 27.7, and rich: 1.5. 51: LAC-Simple average for Latin American and Caribbean countries; LAC-Simple average only for Latin American countries.

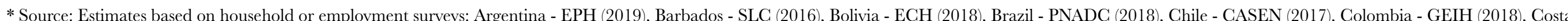
Rica - ENAHO (2018), Ecuador - ENEMDU (2018), El Salvador - EHPM (2019), Guatemala - ENEI (2018), Honduras - EPHPM - (2018), Jamaica - SLC (2015), Mexico - ENIGH (2018), Panama - EPM (2017), Paraguay - EPHC (2018), Peru - ENAHO (2018), Dominican Republic - ENCFT (2017), Suriname - SLC (2017), Trinidad and Tobago - CSSP (2015), Uruguay - ECH (2019). 
Figure 2. Scenario description

- Scenario A $\|$ Scenario $\mathrm{B} \quad \|$ Scenario C

\begin{tabular}{|c|c|c|c|c|c|c|c|c|c|c|c|c|c|c|c|c|c|c|c|c|c|c|c|c|c|c|c|c|c|c|c|c|c|c|c|c|c|}
\hline ARG & BR & & BO & & BRA 21 & & $\mathrm{CHI}$ & & $\mathrm{COL}$ & & CRI & & ECU & & sLv & & $G T$ & & HN & & JAR & & $\mathrm{ME}$ & & PAI & & PR & & PE & & DON & & su & & тто & & URY \\
\hline & & . & & $2^{\circ}$ & & es & & $\sqrt{3}$ & & $\overline{8}$ & & & & & & & & & & & & & & & & & & & & & & & & & & & \\
\hline 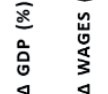 & $\begin{array}{l}\frac{\bar{g}}{0} \\
0 \\
\bar{a}\end{array}$ & $\begin{array}{l}\frac{4}{4} \\
\vdots \\
\vdots \\
3\end{array}$ & $\begin{array}{l}\frac{\bar{g}}{0} \\
0 \\
\bar{a}\end{array}$ & $\begin{array}{l}\frac{4}{4} \\
\vdots \\
3\end{array}$ & $\begin{array}{l}\frac{5}{30} \\
0 \\
0\end{array}$ & 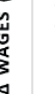 & 通 & 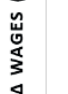 & $\begin{array}{l}\frac{5}{30} \\
\frac{0}{0} \\
4\end{array}$ & 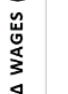 & 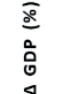 &  & $\begin{array}{l}\frac{\bar{g}}{20} \\
\frac{0}{0} \\
4\end{array}$ & 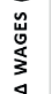 & $\begin{array}{l}\overline{\underline{g}} \\
0 \\
0 \\
4\end{array}$ &  & $\begin{array}{l}\bar{g} \\
\frac{\bar{g}}{0} \\
\bar{a}\end{array}$ & 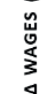 & 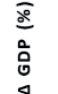 & 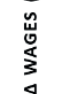 & $\begin{array}{l}\bar{x} \\
\frac{5}{0} \\
4 \\
4\end{array}$ & $\begin{array}{l}\frac{1}{4} \\
\frac{\pi}{3} \\
\frac{\pi}{3}\end{array}$ & $\begin{array}{l}\bar{x} \\
\frac{5}{0} \\
4\end{array}$ & 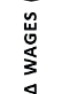 & 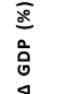 & 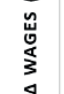 & $\begin{array}{l}\frac{\bar{g}}{3} \\
0 \\
0 \\
4\end{array}$ & 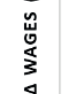 & 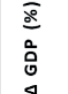 & 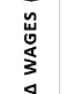 & $\begin{array}{l}\frac{\bar{g}}{30} \\
\frac{0}{0} \\
4\end{array}$ & $\begin{array}{l}5 \\
\frac{4}{0} \\
3 \\
3 \\
4\end{array}$ & $\begin{array}{l}\bar{g} \\
\frac{\bar{g}}{0} \\
4\end{array}$ &  & 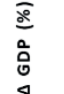 & $\begin{array}{l}0 \\
3 \\
4 \\
4\end{array}$ &  \\
\hline
\end{tabular}

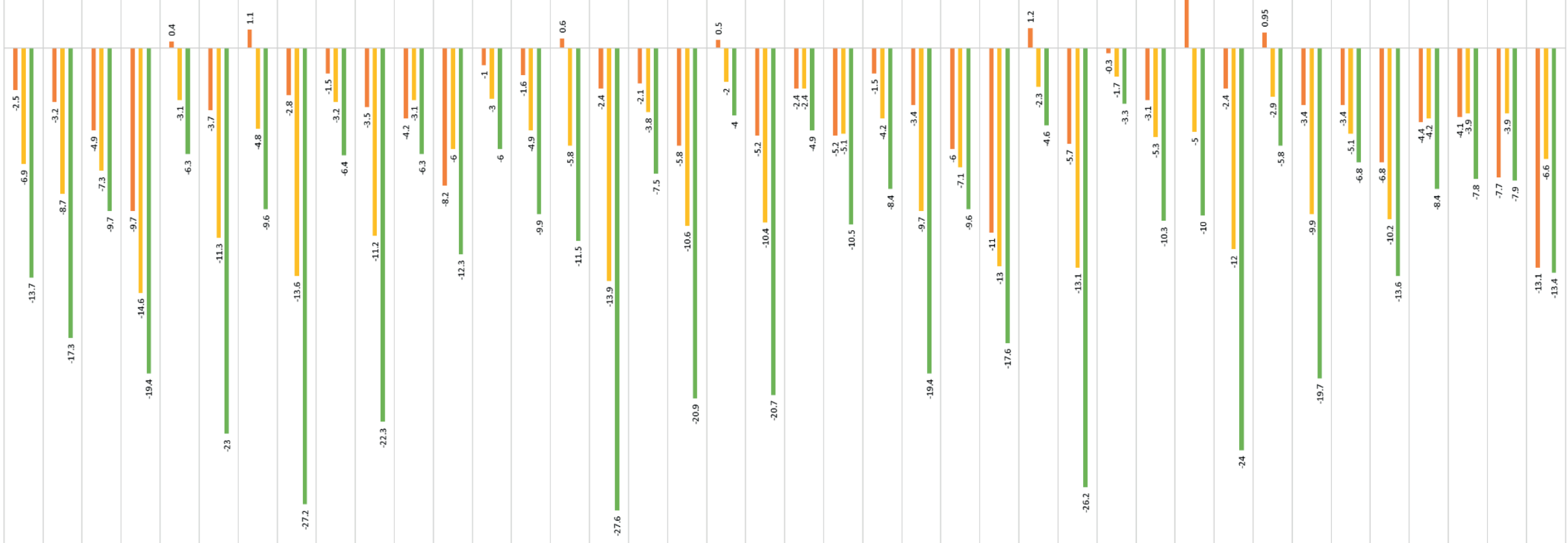





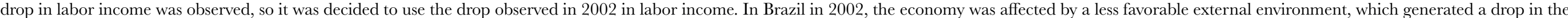
flow of external capital, a depreciation of the real, and a drop in refining rates (IMF, 2003). The impact of the shock led to an increase in inflation and a slowdown in economic growth.

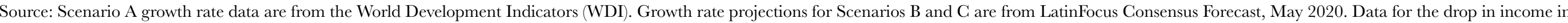
Scenario A come from household or employment surveys, except for Jamaica, which uses data from the International Labor Organization. 
Estimates of the impact on class composition

Table 1 and Figure 3 present the data for the simulation of Scenario C, while Table A.3 in annexes contains the results for the three scenarios $\mathrm{A}, \mathrm{B}$ and $\mathrm{C}$, respectively.

Table 1. Distribution of the population by social class assuming a decrease in labor and non-labor income -Scenario C

\begin{tabular}{|c|c|c|c|c|c|c|c|c|c|c|}
\hline \multirow[b]{2}{*}{ Country } & \multicolumn{5}{|c|}{ Baseline } & \multicolumn{5}{|c|}{ Scenario $\mathrm{C}$} \\
\hline & $\begin{array}{l}\text { Ex- } \\
\text { treme } \\
\text { Poor }\end{array}$ & $\begin{array}{l}\text { Mod- } \\
\text { erate } \\
\text { Poor }\end{array}$ & $\begin{array}{c}\text { Vulnera- } \\
\text { ble Mid- } \\
\text { dle } \\
\text { Class }\end{array}$ & $\begin{array}{c}\text { Consol- } \\
\text { idated } \\
\text { Middle } \\
\text { Class }\end{array}$ & Rich & $\begin{array}{c}\text { Ex- } \\
\text { treme } \\
\text { Poor }\end{array}$ & $\begin{array}{l}\text { Mod- } \\
\text { erate } \\
\text { Poor }\end{array}$ & $\begin{array}{c}\text { Vulnera- } \\
\text { ble Mid- } \\
\text { dle } \\
\text { Class }\end{array}$ & $\begin{array}{l}\text { Consol- } \\
\text { idated } \\
\text { Middle } \\
\text { Class }\end{array}$ & Rich \\
\hline $\begin{array}{l}\text { Argentina } \\
\text { (urban) }\end{array}$ & 9.1 & 9.6 & 36.9 & 42.3 & 2.1 & 12.1 & 12.3 & 41.1 & 33.3 & 1.2 \\
\hline Barbados & 16.8 & 9.8 & 32.1 & 38.6 & 2.7 & 20.2 & 11.5 & 35.1 & 32.0 & 1.3 \\
\hline Bolivia & 14.3 & 11.5 & 41.1 & 32.5 & 0.6 & 19.8 & 15.9 & 41.7 & 22.4 & 0.2 \\
\hline Brazil & 9.6 & 9.3 & 31.7 & 43.7 & 5.7 & 14.7 & 12.4 & 38.7 & 30.9 & 3.4 \\
\hline Chile & 3.1 & 4.5 & 34.4 & 51.5 & 6.5 & 4.8 & 8.3 & 42.9 & 39.7 & 4.3 \\
\hline Colombia & 14.6 & 12.4 & 33.8 & 34.6 & 4.5 & 17.5 & 14.0 & 34.1 & 30.7 & 3.7 \\
\hline Costa Rica & 6.4 & 8.5 & 35.5 & 44.4 & 5.3 & 7.9 & 9.7 & 37.2 & 40.9 & 4.3 \\
\hline Ecuador & 10.6 & 12.0 & 39.7 & 35.6 & 2.0 & 17.8 & 16.6 & 40.8 & 23.9 & 0.9 \\
\hline El Salvador & 11.7 & 16.7 & 48.6 & 22.5 & 0.4 & 19.0 & 21.7 & 44.9 & 14.3 & 0.2 \\
\hline Guatemala & 31.5 & 20.1 & 33.2 & 14.9 & 0.3 & 41.1 & 20.4 & 28.5 & 9.8 & 0.1 \\
\hline Honduras & 36.1 & 18.5 & 31.2 & 13.7 & 0.5 & 39.9 & 18.8 & 29.5 & 11.3 & 0.4 \\
\hline Jamaica $^{21}$ & - & 19.5 & 50.6 & 29.6 & 0.3 & - & 29.3 & 49.8 & 20.7 & 0.2 \\
\hline Mexico & 15.8 & 20.0 & 42.2 & 21.1 & 0.7 & 20.5 & 24.1 & 40.6 & 14.5 & 0.2 \\
\hline Panama & 8.1 & 7.6 & 30.4 & 48.6 & 5.3 & 12.8 & 10.6 & 35.9 & 37.7 & 3.0 \\
\hline Paraguay & 9.3 & 10.3 & 36.8 & 40.7 & 2.9 & 11.1 & 11.6 & 39.0 & 35.9 & 2.5 \\
\hline Peru & 9.2 & 12.0 & 42.6 & 34.6 & 1.6 & 15.1 & 16.2 & 44.2 & 23.6 & 0.9 \\
\hline $\begin{array}{l}\text { Dominican } \\
\text { Republic }\end{array}$ & 6.5 & 11.4 & 46.5 & 34.2 & 1.5 & 11.3 & 15.5 & 47.5 & 24.9 & 0.8 \\
\hline Suriname & 12.4 & 8.8 & 36.5 & 40.1 & 2.2 & 14.5 & 11.4 & 38.1 & 34.5 & 1.6 \\
\hline $\begin{array}{l}\text { Trinidad \& } \\
\text { Tobago }\end{array}$ & 4.1 & 7.9 & 38.2 & 48.4 & 1.4 & 5.7 & 7.6 & 42.0 & 43.8 & 1.0 \\
\hline Uruguay & 1.3 & 2.9 & 24.6 & 65.7 & 5.6 & 1.8 & 4.2 & 29.6 & 60.6 & 3.7 \\
\hline $\begin{array}{l}\text { LAC } \\
\text { Average }^{3 \backslash}\end{array}$ & 12.1 & 11.7 & 37.3 & 36.9 & 2.6 & 16.2 & 14.6 & 39.1 & 29.3 & 1.7 \\
\hline LA Average & 12.3 & 11.7 & 36.8 & 36.3 & 2.8 & 16.7 & 14.5 & 38.5 & 28.4 & 1.9 \\
\hline $\begin{array}{l}\text { Caribbean } \\
\text { Average }\end{array}$ & 11.1 & 11.5 & 39.3 & 39.2 & 1.6 & 13.5 & 14.9 & 41.2 & 32.7 & 1.0 \\
\hline
\end{tabular}

11: The following definitions are used to classify the population according to socioeconomic level: the extreme poor class has a daily per capita income of less than US $\$ 3.1$; the moderate poor class has an income of US\$3.1 to US\$5; the vulnerable middle class, with an income of US\$5 to US\$12.4; the consolidated middle class with a daily per capita income of US\$12.4 to US\$62; the upper class with a daily per capita income greater than US\$62 (in $2011 \mathrm{PPP}$ ). To estimate the US\$5 per day poverty line, this value is multiplied by 30.4168 to obtain a monthly poverty line, and then converted to local currency using the PPP adjustment based on WDI data, and the value is updated using the national CPI for the survey year. 2l: The JSLC database does not have a detailed module of labor and non-labor income, so the national poverty line consisting of per capita household consumption was used to approximate the distribution of social classes. Thus, the poor are defined as those below the per capita poverty line, and an interval of up to 2.5 times the poverty line is assumed for the vulnerable classes; for the middle class an interval of 2.5 and 12.4 times the per capita poverty line, and for the upper class $>12.5$ the national per capita poverty line. Due to this limitation of information, the data are not comparable with the rest of the countries and should be interpreted as an approximation. 31: LAC-Corresponds to the simple average for Latin American and Caribbean countries;

LA-Simple average for Latin American countries. 
The results of Scenario C suggest that for LAC on average, the percentage of the population living in extreme poverty would increase from 12.1 to 16.2 percent, while moderate poverty would rise from 11.7 to 14.6 on average. For the vulnerable middle class, the results suggest an increase of 1.8 percentage points for LAC and a reduction of 7.6 percentage points for the consolidated middle class. In the case of changes in moderate poverty and the vulnerable middle class, an "entry" of population groups falling into that position is combined with the exit of others falling into the corresponding lower category. For the Caribbean countries included in the sample, the results suggest that the poor population (extreme and moderate) would increase from 22.6 to 28.4 percent, and the consolidated middle class would decrease on average by 6.5 p.p.

Figure 3 presents the percentage point changes in the distribution of social classes estimated for Scenario C by country. Brazil is the country with the largest reduction in the consolidated middle class with 12.9 p.p., followed by Chile and Ecuador with 11.8 and 11.7 p.p., respectively. In contrast, Guatemala, El Salvador, and Ecuador are the countries that report the greatest increase in the population classified as extremely poor, with increases of 9.6, 7.2, and 7.1 percentage points, respectively. Table A.4 in the Annex presents the changes in percentage points in the distribution of social classes for all scenarios.

Results on poverty are in line with what is found in Lustig, Martínez, Sanz and Younger (2020), under the scenario that they name of "dispersed losses". ${ }^{8}$

For Latin America and the Caribbean as a whole, the increase of 7 percentage points in the percentage of the poor population (extreme and moderate) in this scenario is equivalent to an increase of 44 million people in this condition-26.2 and 17.7 million people in extreme and moderate poverty, respectively (see Table A.5 in the Annex). On the other hand, the vulnerable middle class increases by 15.5 million, while the consolidated middle class observes a decrease of approximately 52 million people (Table 2$){ }^{9}$

8 Even though the methodology is different and the threshold for the poverty line is $\$ 5.5 \mathrm{PPP}$, Lustig et al. (2020) estimate an increase in poverty of 4.9 p.p. for Argentina (urban), 5.1 p.p for Colombia, 8.1 p.p. for Mexico and 4.5 p.p. for Brazil.

9 It is worth noting that our estimates reflect a similar magnitude to those made by ECLAC (2020b) - which assume impacts on employment and labor income for the different productive sectors. Using data from 17 countries in the region, ECLAC projects an increase in poverty equivalent to 45.5 million people, of which 28.5 million people would go on to live in conditions of extreme poverty. 
Figure 3. Changes in percentage points in the distribution of social classes -Scenario $\mathrm{C}$

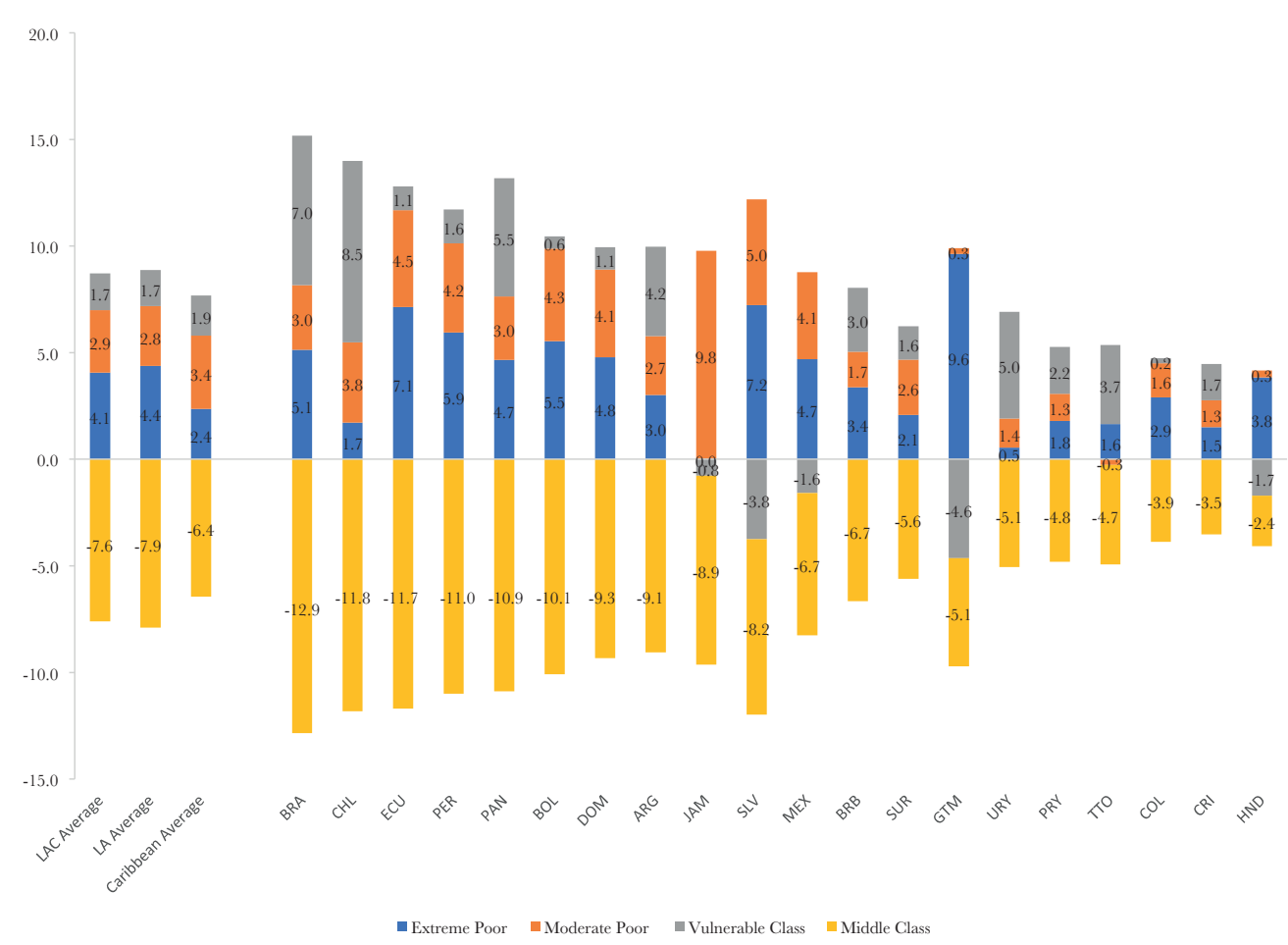

Note: The data for Latin America and the Caribbean (LAG), Latin America (LA) and the Caribbean countries are simple averages.

Source: Ditto.

Table 2. Change in the number of people in the distribution of social classes -Scenario C

\begin{tabular}{|c|c|c|c|c|}
\hline Country $^{1 \backslash}$ & $\begin{array}{c}\text { Poor } \\
\text { (extreme \& moderate) }\end{array}$ & $\begin{array}{l}\text { Vulnerable middle } \\
\text { class }\end{array}$ & $\begin{array}{c}\text { Consolidated middle } \\
\text { class }\end{array}$ & Rich \\
\hline Brazil & $16,700,282$ & $14,339,417$ & $-26,292,857$ & $-4,746,842$ \\
\hline Mexico & $11,173,472$ & $-2,027,153$ & $-8,503,122$ & $-643,209$ \\
\hline Peru & $3,368,859$ & 529,300 & $-3,660,546$ & $-237,613$ \\
\hline Colombia & $2,177,937$ & 114,017 & $-1,878,660$ & $-413,294$ \\
\hline Ecuador & $1,996,844$ & 191,158 & $-2,000,204$ & $-187,798$ \\
\hline Argentina & $1,636,024$ & $1,189,959$ & $-2,571,081$ & $-254,902$ \\
\hline Guatemala & $1,731,404$ & $-810,631$ & $-887,952$ & $-32,821$ \\
\hline Bolivia & $1,119,840$ & 63,661 & $-1,143,470$ & $-40,031$ \\
\hline Chile & 975,487 & $1,515,107$ & $-2,106,323$ & $-384,271$ \\
\hline Dominican Republic & 907,541 & 107,651 & $-951,752$ & $-63,441$ \\
\hline El Salvador & 816,843 & $-251,740$ & $-551,144$ & $-13,959$ \\
\hline Honduras & 375,593 & $-155,062$ & $-213,623$ & $-6,908$ \\
\hline Panama & 311,300 & 226,165 & $-443,949$ & $-93,517$ \\
\hline Jamaica $^{2 \backslash}$ & 266,477 & $-21,195$ & $-241,391$ & $-3,891$ \\
\hline Paraguay & 213,473 & 153,140 & $-334,849$ & $-31,764$ \\
\hline Costa Rica & 138,115 & 85,037 & $-176,264$ & $-46,888$ \\
\hline Uruguay & 66,886 & 176,469 & $-177,839$ & $-65,516$ \\
\hline Suriname & 23,075 & 7,776 & $-27,754$ & $-3,096$ \\
\hline Trinidad \& Tobago & 18,782 & 50,774 & $-63,984$ & $-5,572$ \\
\hline
\end{tabular}


Table 2 (continued). Change in the number of people in the distribution of social classes -Scenario C

\begin{tabular}{lcrrr}
\hline \multicolumn{1}{c}{ Country $^{11}$} & $\begin{array}{c}\text { Poor } \\
\text { (extreme \& moderate) }\end{array}$ & $\begin{array}{c}\text { Vulnerable middle } \\
\text { class }\end{array}$ & $\begin{array}{c}\text { Consolidated middle } \\
\text { class }\end{array}$ & Rich \\
\hline Barbados & 10,631 & 6,336 & $-14,076$ & $-2,891$ \\
LAC Total & $44,028,865$ & $15,490,186$ & $-52,240,838$ & $-7,278,224$ \\
LA Total & $43,709,900$ & $15,446,495$ & $-51,893,633$ & $-7,262,774$ \\
Caribbean Total & 318,965 & 43,690 & $-347,205$ & $-15,450$ \\
\hline
\end{tabular}

1।: To estimate the flow of people, the population data estimated with the expansion factor from household surveys is used, except for Jamaica the data comes from STATIN 2015, and for Mexico the data corresponds to the most recent value reported by INEGI. 21: The JSLC database does not have a detailed module of labor and non-labor income, so to approximate the distribution of social classes the national poverty line was used, which consists of the per capita consumption of the households. Thus, the poor are defined as those below the per capita poverty line, and an interval of up to 2.5 times the poverty line is assumed for the vulnerable classes; for the middle class an interval of 2.5 and 12.4 times the per capita poverty line, and for the upper class $>12.5$ the national per capita poverty line. Due to this limitation of information, the data are not comparable with the rest of the countries and should be interpreted as an approximation.

\section{Source: Ditto.}

On the other hand, Figure 4 compares the poverty gap for the population classified as poor (extreme and moderate) before the health crisis, with the results of the most pessimistic scenario (Scenario C). These results give an idea of the degree to which the population already classified as poor will increase its level of precariousness - this, coupled with the effect of the shift in population from the middle classes to the poor due to the economic contraction (see Table A.6 in the Annex). The comparison reveals a significant increase of about 10 points in all cases. In percentage terms, Brazil, Guatemala, and Bolivia are the countries that show the greatest increase in the poverty gap resulting from the impact on household income and employment.

Figure 4. Poverty Gap for the Poor (Extreme and Moderate) G

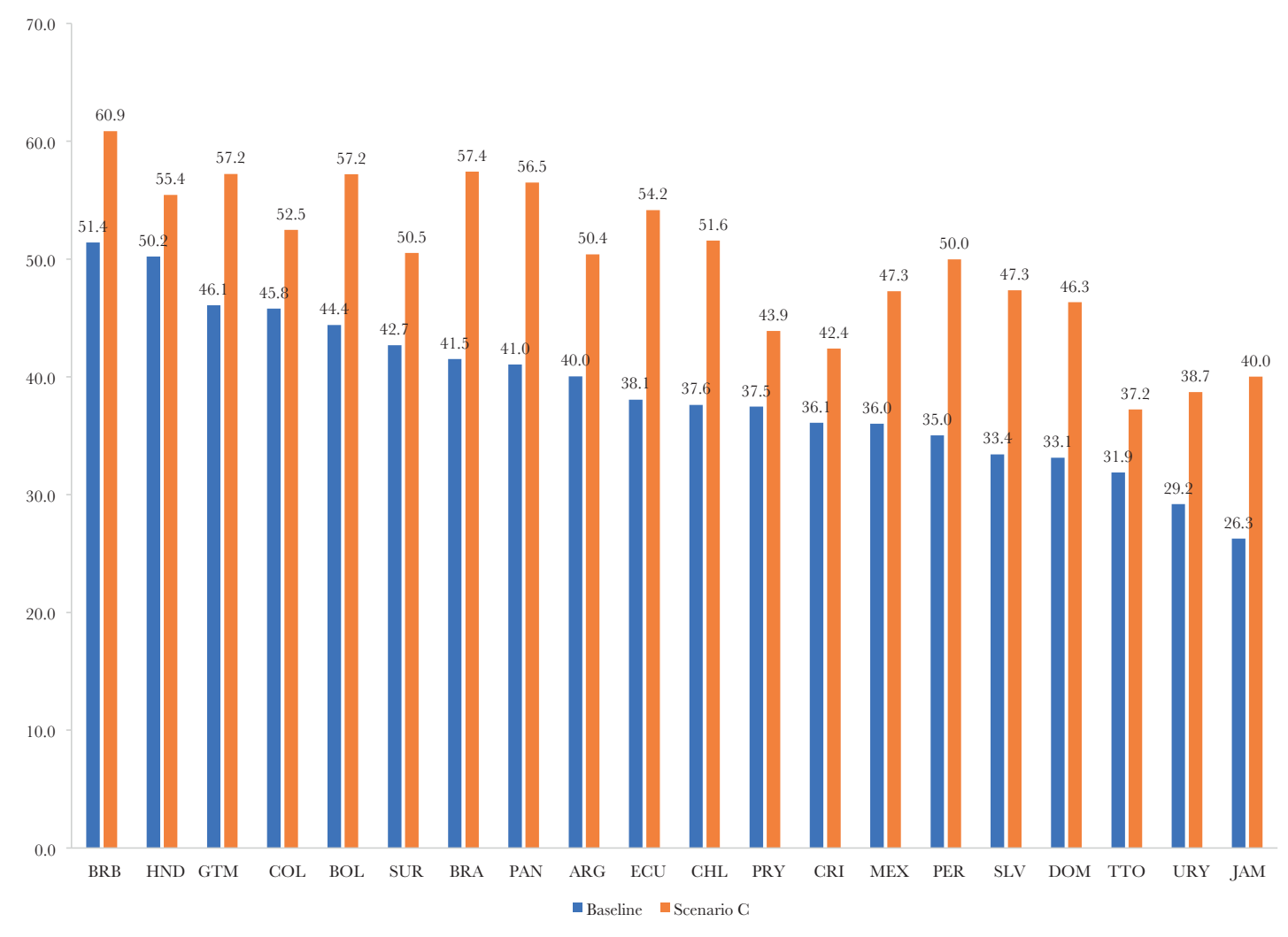

Source: Ditto. 
An important aspect to emphasize is that the results presented are derived from the specific assumptions and parameters for approximating the transmission channels between economic performance and household income, explained in previous sections. In this regard, a recent IDB study (2020o) that includes Mexico, Guatemala, Honduras, El Salvador, Costa Rica, Panama and the Dominican Republic uses time series econometric models and microdata from household surveys to estimate the relationship between employment, GDP and income, and thus also approximate the impact of COVID-19 on household poverty and inequality. It should be noted that although the methodology for calculating elasticities is different, the results for this set of countries are consistent with those in this document, which can be interpreted as proof of robustness in the sense that by varying a central aspect of the methodology, the conclusions are similar. ${ }^{10}$ Table A.13 in the annex presents the corresponding comparison.

Estimates of "lifestyle" implications for the middle classes

One of the consequences of the expansion of social classes observed in previous decades in the region is that the population, having a higher income, can access new assets that improve their welfare. With the social decline that will potentially be generated by the economic contraction of 2020, significant consequences are therefore expected in the opposite direction in the consumption patterns of goods and services. To give an idea of the potential effects in this sense, Figure 5 presents asset holdings as a function of social class.

For example, in the indicator of percentage of homes with refrigerators, Bolivia and Peru register more marked differences in the possession of this asset between the poor classes and the consolidated middle class. On the other hand, in terms of ownership of vehicles, all the countries in the region with information show significant gaps between the poor and vulnerable classes, and the consolidated middle class and the rich. Therefore, it is possible that the possession of durable goods of this type for the poor and vulnerable population will be reduced as a result of the current crisis.

With respect to connectivity indicators, class differences are more evident for Jamaica, Brazil, Paraguay, and Mexico, with gaps of 81, 72.6, 70.3, and 70.2 p.p., respectively, between poor and rich households. While Barbados and Uruguay have the smallest class differences in computer ownership. For the indicator of Internet access in the home, Jamaica, Peru, Paraguay, and Mexico are the countries with the greatest differences between classes. Finally, Tables A.7 and A.8 in the Annex show data on the ownership of rented and owned housing by social class.

10 One of the assumptions of our analysis is that the elasticity GDP/wage income in the global financial crisis (or other previous crises) is the same as the elasticity today, which is not necessarily true. The consistency with the results presented in IDB (2020o), where elasticities are estimated across all years and not only in times of crises, are reassuring in this sense. 
Figure 5. Household asset holdings by socioeconomic level

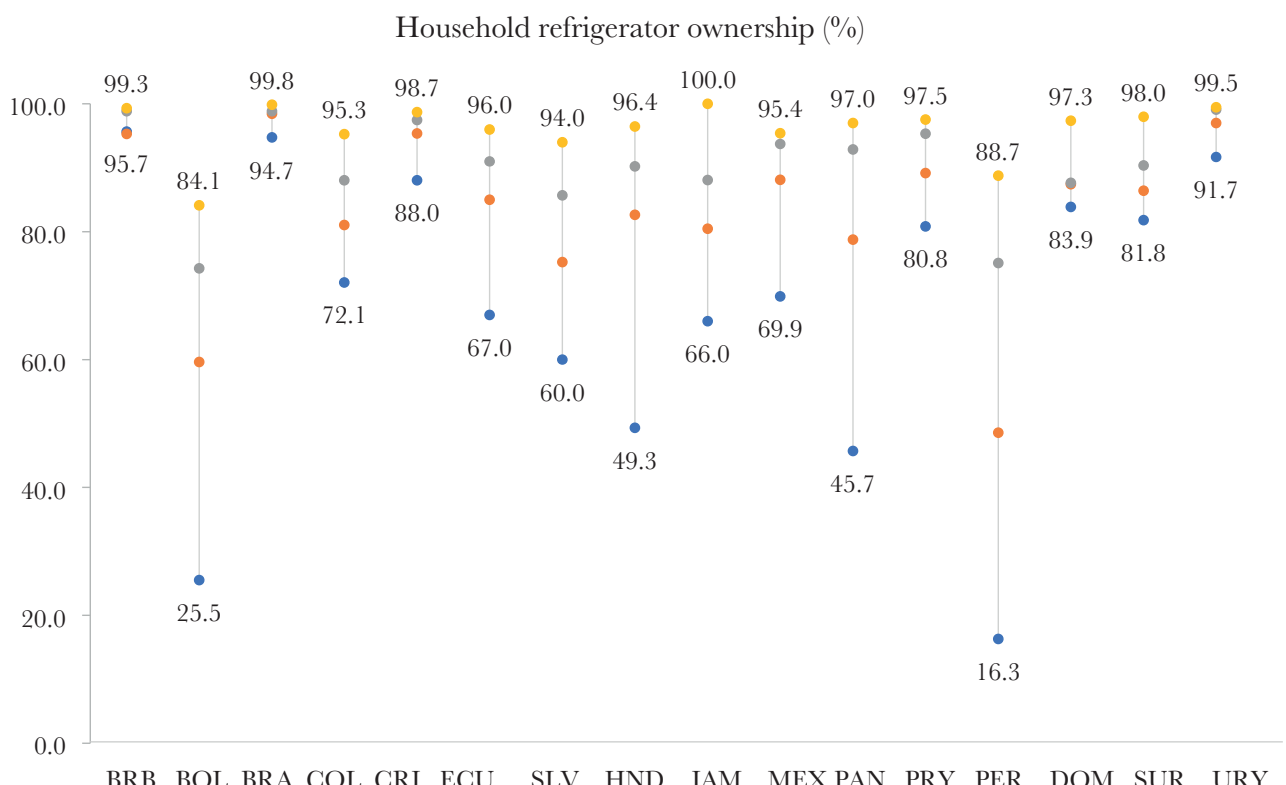

- Poor • Vulnerable • Middle Class • Rich

Household car ownership (\%)

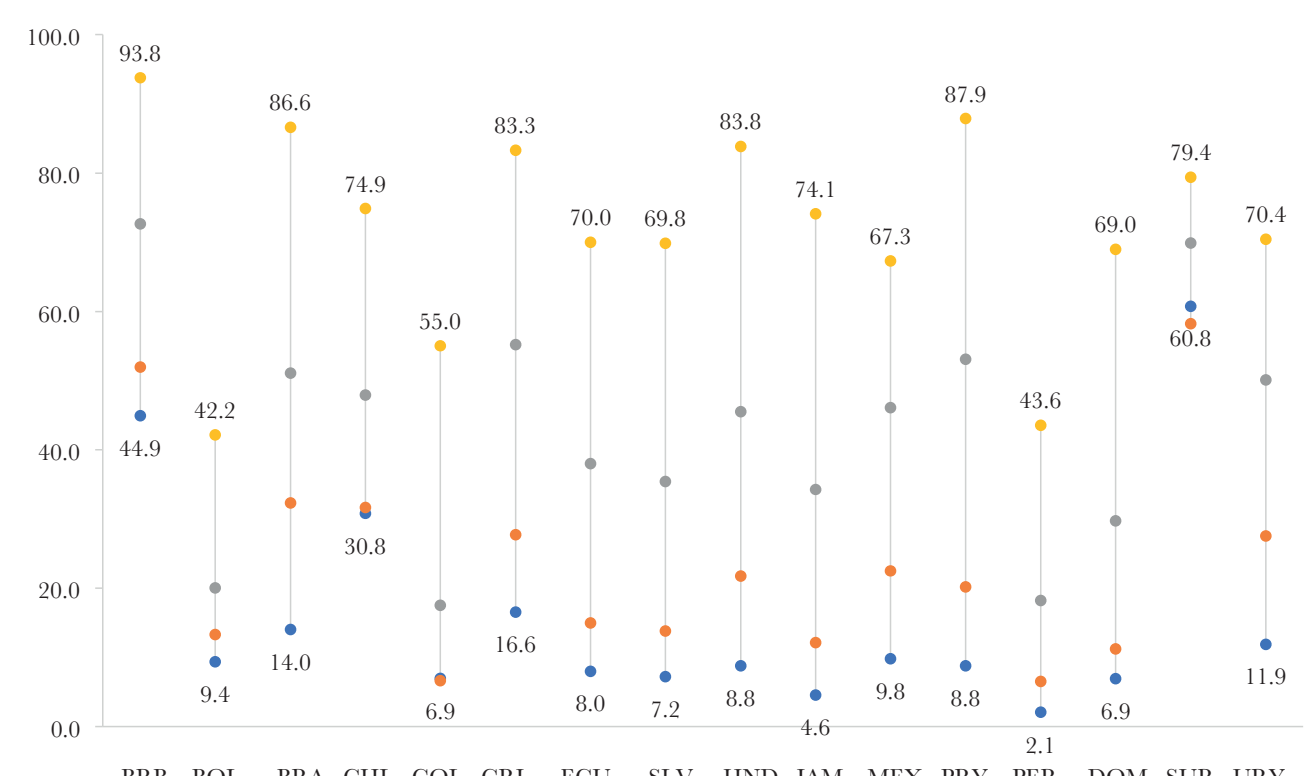

BRB BOL BRA CHL COL CRI ECU SLV HND JAM MEX PRY PER DOM SUR URY 
Figure 5 (continued). Household asset holdings by socioeconomic level

Household computer ownership (\%)

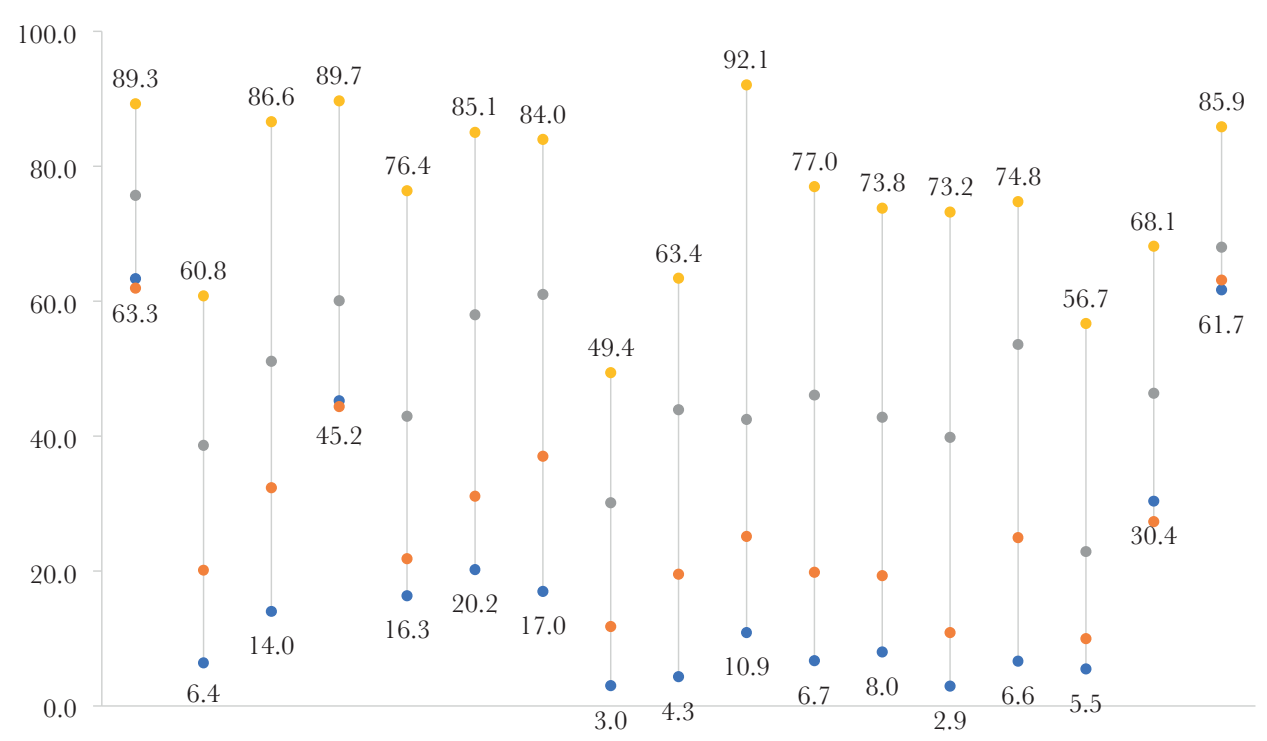

BRB BOL BRA CHL COL GRI ECU SLV HND JAM MEX PAN PRY PER DOM SUR URY

- Poor • Vulnerable • Middle Class • Rich

Household access to Internet $(\%)$

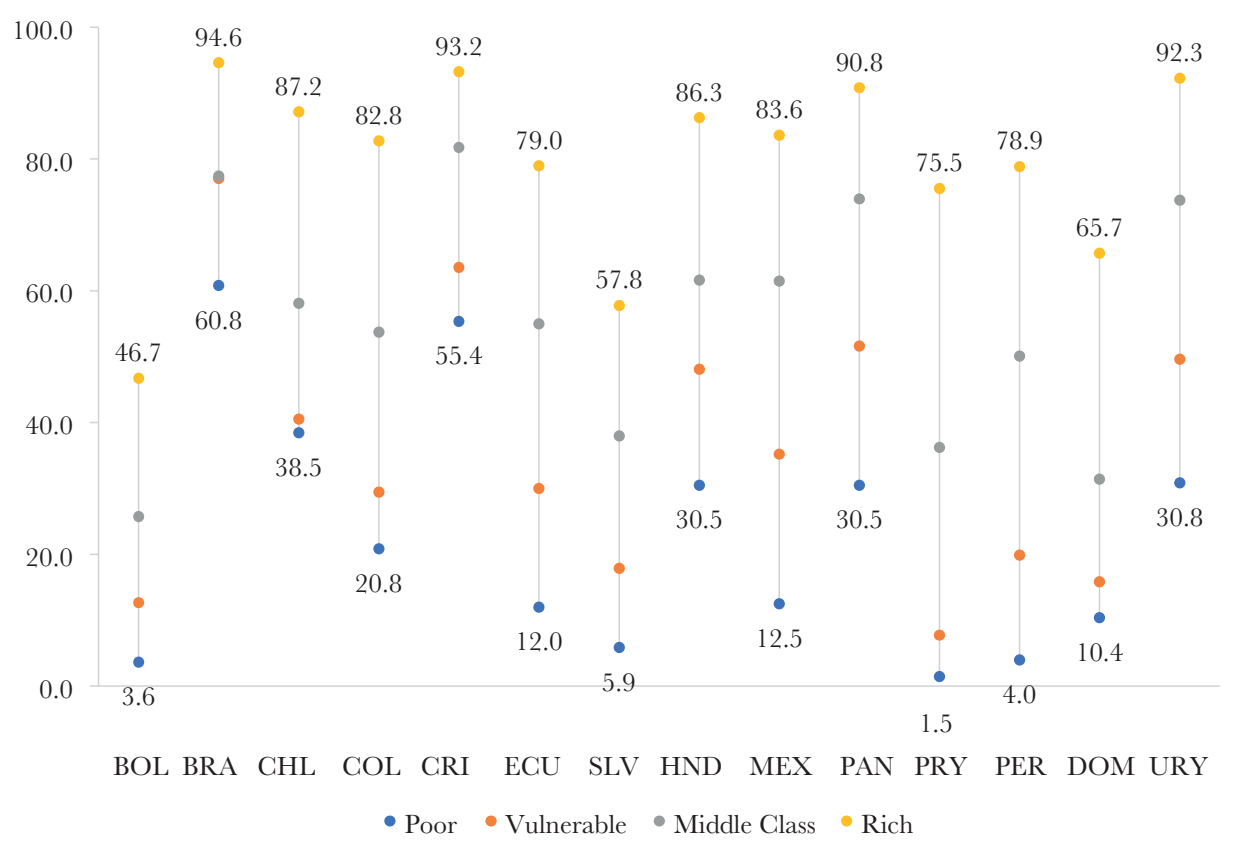

Source: Ditto.

Sociodemographic profile of the population that changes social class

Figure 6 shows the characteristics of the population that goes from being classified as consolidated middle class in the base scenario to vulnerable middle class in scenario $\mathrm{C}$ - which is the most pessimistic.

With respect to age, in all countries, approximately 45 percent of the population moving from consolidated to vulnerable middle class is in the range of 25 to 64 years, while the distribution by sex is similar among the countries of the region (this reflects that the characteristics of 
the households in the vulnerable middle class, at least in these dimensions, is similar to the total population). It should be noted that the largest proportion of the population that changes from the consolidated middle class to the vulnerable class resides in urban areas, with the highest proportions observed in Suriname, Peru, Brazil, Chile and Bolivia (Table A.9). This may reflect the fact that the expansion of the middle class observed in the region in the previous decade coincided with an acceleration in the population's urbanization process. In terms of educational level, the distribution varies by country. For example, in Mexico, Barbados, Peru, Bolivia, Chile, and Argentina, the largest percentage of people aged 25 and over who move from the consolidated middle class to the vulnerable class has a tertiary education-complete or incomplete-or an education equivalent to upper secondary (between nine and 12 years of education), while in the other countries the largest percentage of the population aged 25 and over who move from one class to another has a lower level of education. The analysis of the data shows that workers with higher levels of education are more likely to move around, which implies that education is not necessarily a proxy for resilience in this context.

Figure 6. Socio-demographic profile of the population of Latin America and the Caribbean that moves from a consolidated middle class to a vulnerable middle class $(\%)$

LAC

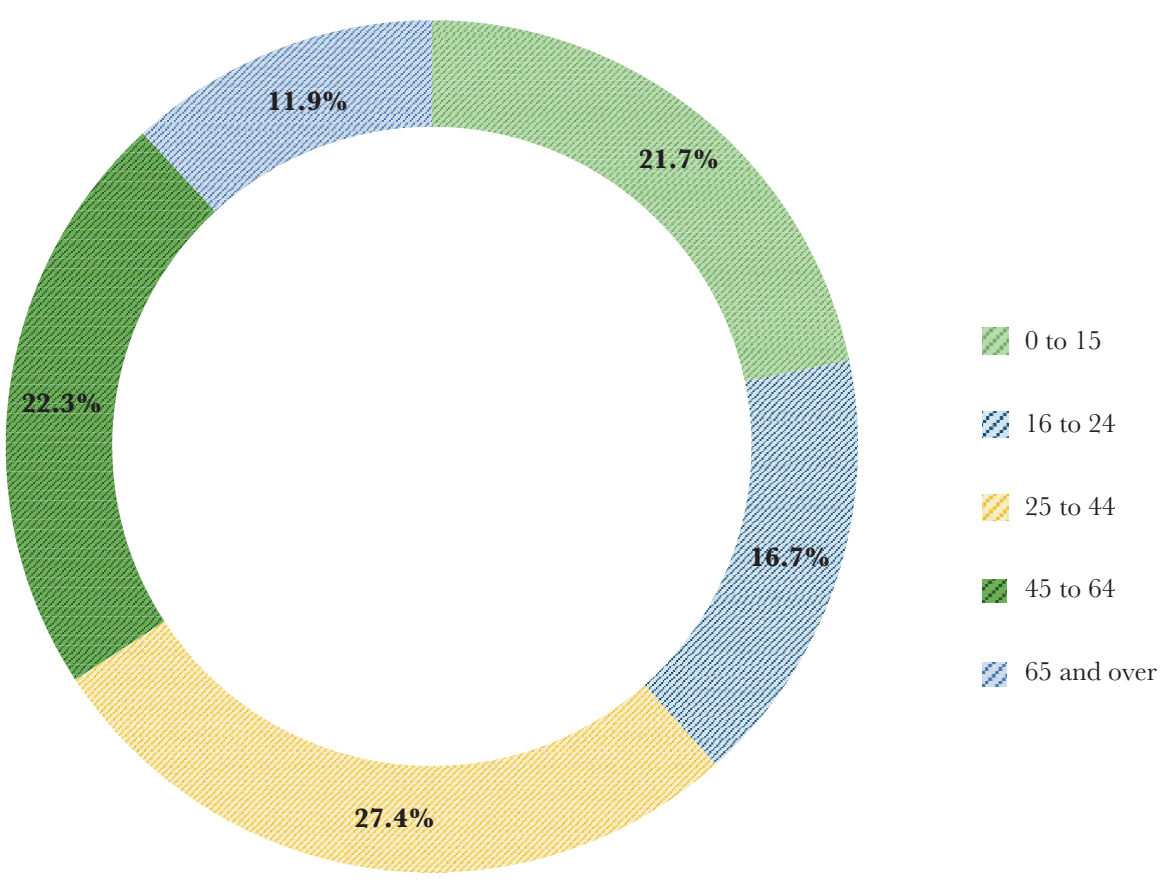


Figure 6 (continued). Socio-demographic profile of the population of Latin America and the Caribbean that moves from a consolidated middle class to a vulnerable middle class $(\%)$

LAC

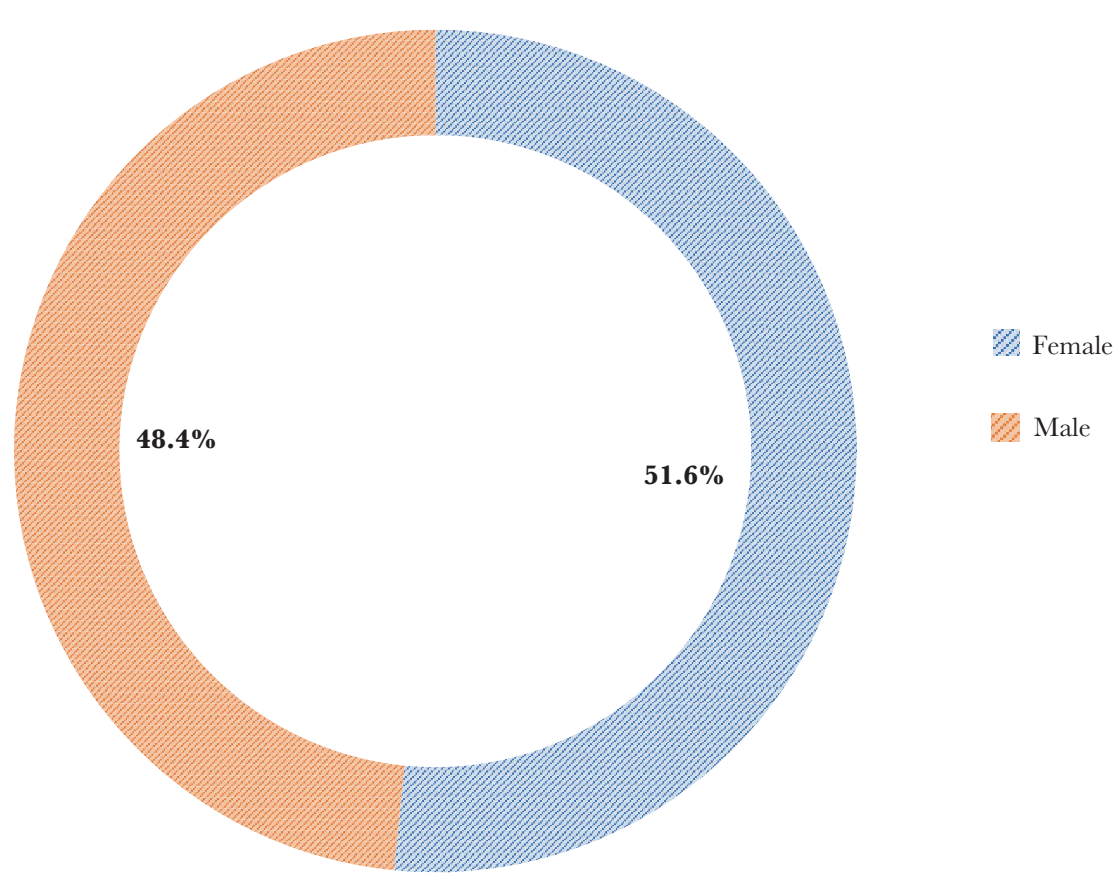

LAC

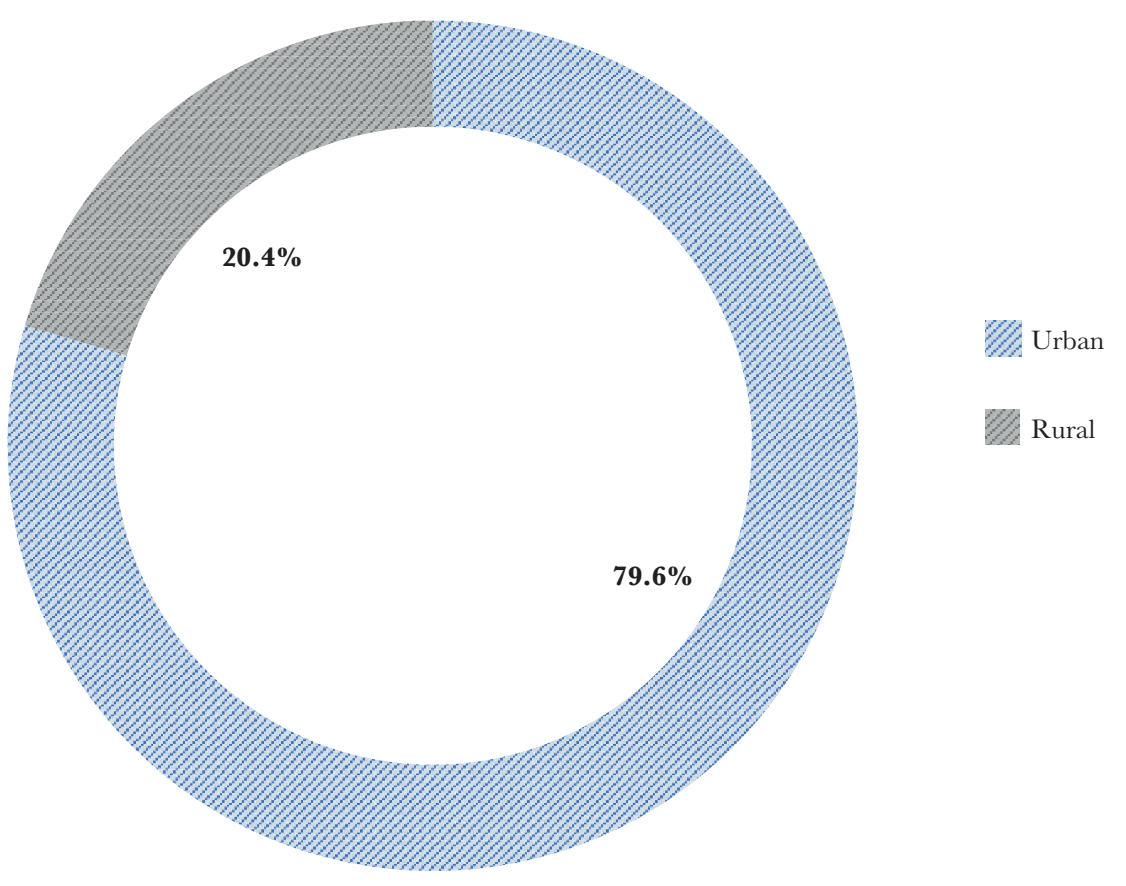


Figure 6 (continued). Socio-demographic profile of the population of Latin America and the Caribbean that moves from a consolidated middle class to a vulnerable middle class $(\%)$

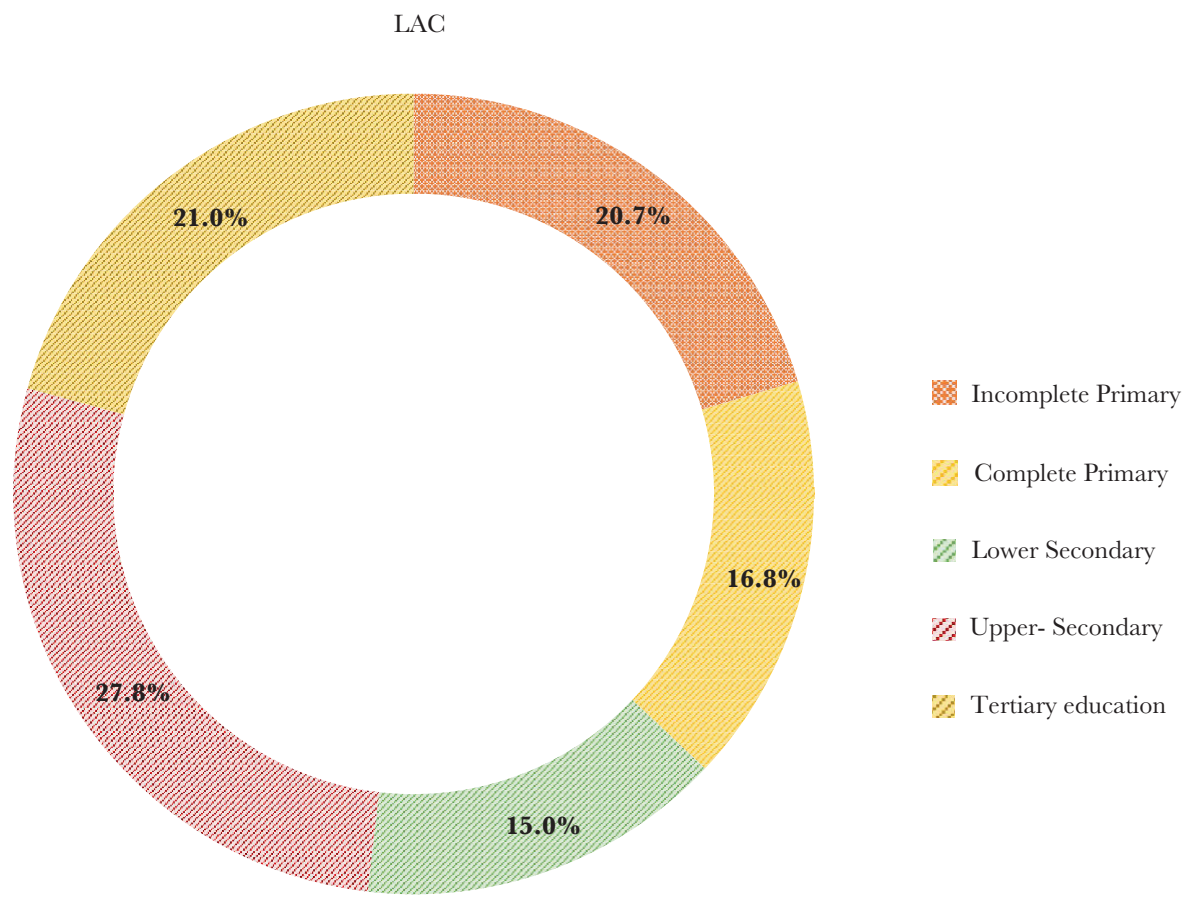

Source: Ditto.

Figure 7 presents the socio-demographic profile of the population moving from the vulnerable middle class in the baseline scenario to poor (extreme and moderate) in Scenario C. It is notable that compared to the results in Figure 6, a higher percentage of people between 0 and 15 years old are affected by the impact, moving from the vulnerable middle class to poor. On the other hand, Barbados, Trinidad and Tobago, El Salvador, Chile, and the Dominican Republic have on average a higher percentage of women moving from the vulnerable middle class to the poor (Table A.10). This suggests that among vulnerable middle-class households, there is a relatively high percentage of households headed by women.

It is also observed that this transition affects more people living in rural areas. ${ }^{11}$ In terms of the distribution of the educational level of the population 25 years of age and older, a greater percentage of the affected population has completed or incomplete primary schooling, with values above 60 percent in Costa Rica, Ecuador, Honduras, Guatemala, El Salvador, Paraguay, and the Dominican Republic, which contrasts with the profile of the population changing from the consolidated middle class to the vulnerable, who have more schooling (Figure 6).

11 A closer exploration of the data in each country shows that in general, the reason is that rural households have lower incomes, and are closer to the extreme poverty line. Thus, the shock actually made a large proportion of these households "cross" the extreme poverty line threshold. Urban households have incomes that are generally higher above the extreme and moderate poverty lines, which implies that the shock does reduce their incomes considerably, but not in all cases to the extent to push them across the line. 
Figure 7. Socio-demographic profile of the population moving from vulnerable to poor class (extreme and moderate)

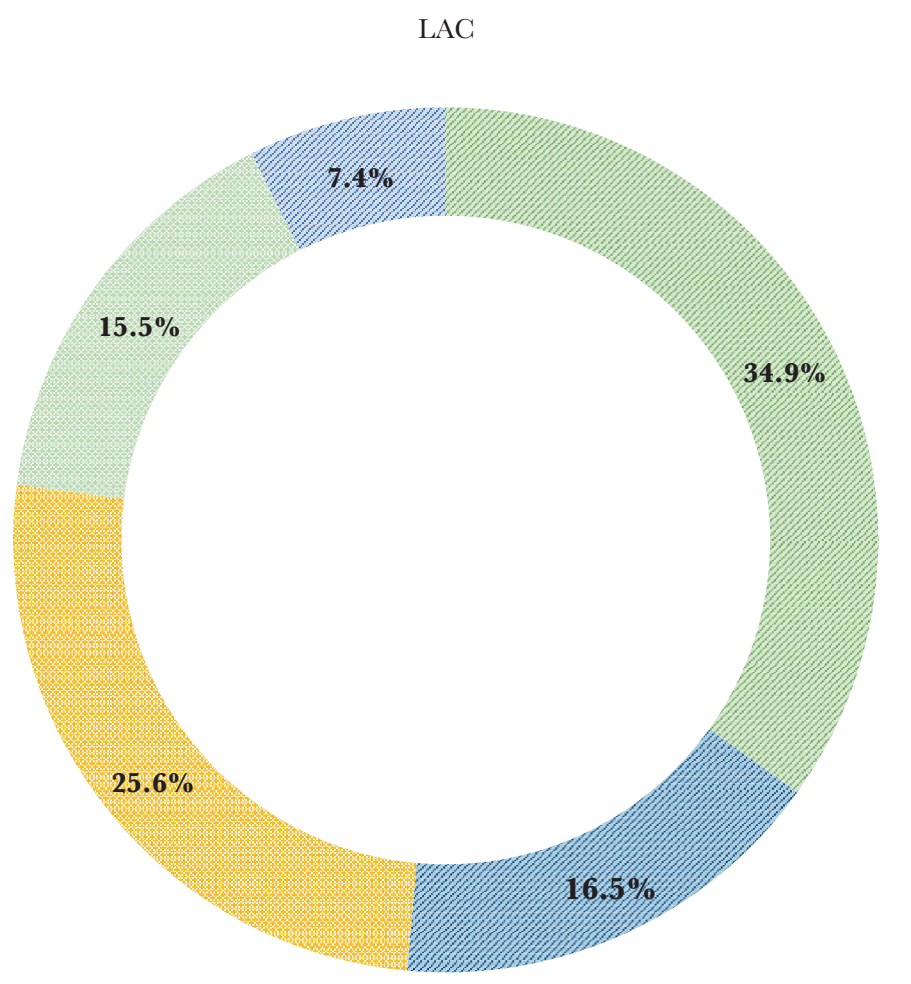

$\mathscr{\gtrless} 0$ to 15

ஜ 16 to 24

25 to 44

2. 45 to 64

$\mathscr{W} 65$ and over

LAC

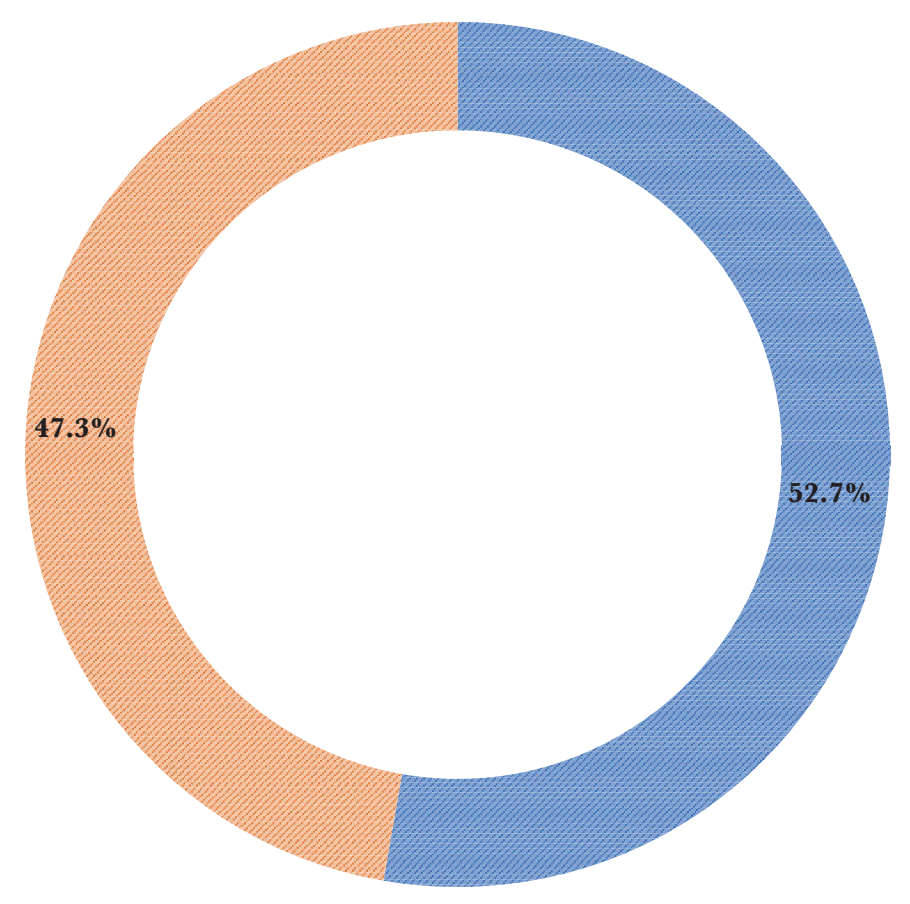

a Female

Z Male 
Figure 7 (continued). Socio-demographic profile of the population moving from vulnerable to poor class (extreme and moderate)

LAC



LAC

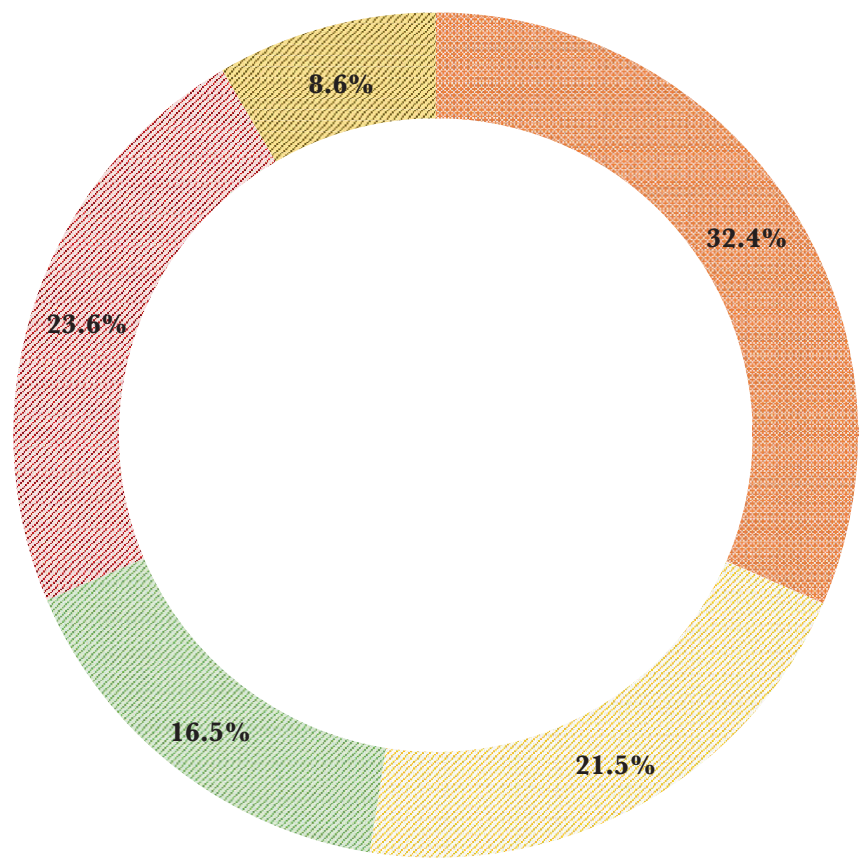

Source: Ditto.
Wrban

Wural

\footnotetext{
Incomplete

Primary

Complete

Primary

$\mathbb{Z}$ Lower

Secondary

\# Upper-

Secondary

$\mathscr{Z}$ Tertiary

education
}

\section{Interventions with the potential to cushion impacts}

The potential negative economic effects of the pandemic have generated intense concern among governments in the region. In addition to the widespread impact on the population, as mentioned above, there are the additional challenges of high labor informality and high social inequality, making it more complex to design interventions that can reach all groups of the population. In general terms, the interventions identified in recent studies can be classified into the following 4 types (OECD, 2020; Blackman, et al., 2020) ${ }^{12}$ :

12 For a more detailed explanation of the policies implemented by Argentina, Chile, Peru, Bolivia, Brazil, Mexico, Colombia, Ecuador, Uruguay and Costa Rica, see Blofield, Giambruno and Filgueira (2020). 
- Expansion of existing social programs, which can be done vertically (momentarily increasing the benefits offered) and horizontally (including additional population groups);

- Formal labor market instruments, including unemployment insurance, incentives to employers to avoid layoffs and salary reductions, postponement of tax and social security contribution payments, and soft loans, among others (IDB, 2020);

- Instruments for informal workers, including training scholarships, temporary employment, temporary transfers, and credit on demand, among others (Busso, Camacho, Messina, \& Montenegro, 2020; IDB, 2020); and

- Support for self-employed workers (registered and unregistered as taxpayers for tax purposes, and as contributors to social security systems), such as incentives for formalization, temporary transfers, and soft loans (IDB, 2020).

Below are some estimates on the potential that these types of interventions could have to mitigate the impacts on poverty in the countries analyzed. For this exercise, the percentages of the population in each social group after the Covid-19 effect under Scenario C, are compared with the percentages that result after simulating the effect of each intervention. The difference is interpreted as a potential "buffer" effect on the number of poor people (extreme and moderate) for each strategy. Tables A.11 and A.12 in the annexes present the results of the policies in greater detail.

In all cases, a period of six months is assumed for the use of the different supports. ${ }^{13}$ In addition, it is assumed that the interest rate is zero, and that the active rate is equal to the passive rate, so that the fiscal impact is reduced to the administrative cost of implementation (which is assumed to be zero cost for the purposes of the simulation). ${ }^{14}$

Tables 3 and 4 summarize the results, as well as the costs of implementing each option relative to GDP in each country. Each alternative is discussed below. ${ }^{15}$

\section{Policy Intervention 1: Implementing transfers for the unemployed (unemployment insurance)}

The first intervention consists in introducing a transfer similar to an unemployment insurance -pre-pandemic- most of the countries in the region did not have this social protection mechanism -according to Végh, and others, (2019) in Latin America only Argentina, Brazil, Chile, Colombia, Ecuador, and Uruguay had current unemployment insurance programs before 2019. On the other hand, information from ECLAC's Covid-19 Observatory indicates that eight Latin American countries and six Caribbean countries have implemented unemployment insurance mechanisms as a social protection measure, including actions to promote the flexibility of existing unemployment insurance schemes. ${ }^{16}$

13 It is hard to predict how long interventions will last. The advantage of having a fixed period for interventions across countries (i.e. 6 months) is that: 1) we can compare them across countries, and 2) it is easy to calculate what would happen if interventions lasted for a shorter period, or for longer. For example, if interventions lasted 3 months only, the costs and benefits attributed to the 6-month intervention would have to be halved.

14 Every intervention will also incur into nonzero administrative costs, which will vary by type of intervention. Implementing a vertical expansion of programs that already benefit from an existing administrative infrastructure will be certainly cheaper than other interventions that create new schemes. We assume zero administrative costs only for simplicity, but this needs to be considered when interpreting the results of the analysis.

15 It is also to be noted that interventions target different populations, achieve different goals and can be useful in different phases of the pandemic shock. While interventions 2 (support for the self-employed) and 4 (rescheduling tax and social security contribution payment) can help workers face the negative shock and preserve their jobs, once jobs are lost, interventions supporting the unemployed or transfers to the most vulnerable will be necessary. Once the recovery starts, however, interventions 2 and 4 might be needed again to encourage employment. The different interventions can then be considered complementary.

16 According to information from ECLAC's Covid-19 Observatory, Argentina, Brazil, Chile, Colombia, Costa Rica, Guatemala, Peru, and Uruguay have implemented social protection measures for unemployment insurance. While in the Caribbean, the Bahamas, Belize, Barbados, Dominica, Grenada, and Saint Lucia have implemented measures to make unemployment schemes more flexible and include special funds for workers in the tourism sector. 
To simulate this intervention, the following scheme is assumed. Granting a transfer equivalent to the monthly poverty line of $\$ 5$ per capita per day in 2011 PPP for 6 months to people who are unemployed and actively seeking employment. To identify the beneficiary population, information from unemployed people in household surveys is used and the value of the poverty line is assigned to them. Subsequently, the household's per capita income is recalculated, as well as the population on each threshold. It is worth noting that if the unemployment rate increases - as a result of the current economic crisis - more than our estimates suggest, this number will be underestimated.

As can be seen in Table 3, this measure registers the highest percentage of buffering of the increase in poverty in Argentina, Barbados, Suriname, and Chile. Because of its magnitude, it can be an effective policy for reversing part of the economic impact of the health crisis.

For the region, its fiscal cost is estimated on average at 0.2 percent of GDP, with the highest value for Honduras at 0.5 percent of GDP. The highest cost-effectiveness is observed in Peru, Ecuador, Colombia, Brazil, Panama, Costa Rica, and the Dominican Republic (Table 4).

\section{Policy Intervention 2: Support for independent workers (self-employed)}

The second intervention consists of providing support to workers classified as "self-employed" or independent, which includes both formal and informal employment. Simulations are made using microdata from household surveys to identify workers classified as "self-employed" who are charged with the monthly value of the poverty line of U\$5 per capita per day PPP for 2011. Subsequently, the household's per capita income is recalculated, as well as the distribution of the population on each threshold. With respect to similar measures implemented in the region's countries, data from ECLAC's Covid-19 Observatory indicate that Argentina, Brazil, Colombia, Chile, Guatemala, Paraguay and Peru provide for such transfers to the informal sector, while the Bahamas, Barbados, Dominica and Jamaica allocate funds for self-employed workers who do not have unemployment insurance benefits.

Overall, for most countries, this is the alternative with the greatest potential for poverty alleviation, which is associated primarily with the high levels of informality in the region. Among the countries reporting the greatest reduction in poverty are Peru, El Salvador, Bolivia, and Ecuador. The fiscal cost of this type of intervention in these countries is 1.6, 1.6, 1.4, 1.5 and 1.6 percent of GDP, respectively (Table 3). The highest cost-effectiveness ratio is recorded in Chile, Argentina, Uruguay, Paraguay, and Bolivia (Table 4).

\section{Policy Intervention 3: Doubling Support for Social Programs}

The third intervention consists of doubling the value of social program support received for 6 months by those who already benefit from them. This type of intervention has been implemented in 24 countries in Latin America and the Caribbean, according to information compiled by ECLAC's Covid-19 Observatory.

To implement the simulation, microdata from household surveys are used to identify those individuals who reported receiving monetary transfers from a social program; each person is assigned an amount equivalent to the amount of the transfers received in the month prior to the survey, and subsequently the household's per capita income and the distribution of the population at each threshold are recalculated. The results suggest that in Bolivia, Brazil, Ecuador, Panama, and Peru, this measure would cushion between 2 and 3 points of the increase in poverty, and for the region, on average, would represent a fiscal cost equivalent to 0.2 percent of GDP (see Table 3). This policy has a higher cost-effectiveness ratio in Mexico, Honduras, and Guatemala (Table 4). 
The reduction in poverty that we predict is similar to what is found in Lustig, Martínez, Sanz and Younger (2020) for Argentina, Brazil and Colombia. ${ }^{17}$

\section{Policy Intervention 4: Rescheduling Tax and Social Security Contribution Payments}

Finally, another of the most favored alternatives in the region, according to the policy briefs mentioned above, is to reschedule tax and social security contribution payments. The logic behind this type of alternative is that postponing payments provides companies with liquidity to maintain their staff and salaries, shifting obligations to the future when the financial situation is expected to be significantly better.

To carry out this exercise, microdata from household surveys are used to identify formal workers - defined as those who are affiliated with or contribute to a social security institution and it is assumed that workers under this classification will not record the drop in total income corresponding to each of the macroeconomic scenarios. When counted as a credit, the fiscal resources required in this case will be equivalent to the differential in the active and passive interest rate for the central government - that is, the payments of taxes and contributions that would not be made in the reference months would begin after a period of 6 months; the payment modalities may be made in different terms, and the longer the term, the less negative the effect on the liquidity of the companies. Assuming that both are equivalent, this policy does not generate a net fiscal cost after the repayment period.

According to the simulations, in this scenario countries such as Brazil, El Salvador, Guatemala and Guatemala are the ones that report the highest percentage points of poverty buffer, while Barbados, Colombia and Paraguay are the ones that report results lower than 1 p.p. (Table 3).

Figure 8 summarizes the results for the 4 policy alternatives explored, and it can be seen that the option with the greatest potential for cushioning is transfers to self-employed workers, followed by rescheduling the payment of contributions for formal workers. Overall, the cost of the 4 alternatives ranges from 0.4 percent of GDP for Trinidad and Tobago to 4.1 percent for Bolivia.

It is interesting to note that there is variation in the cost-effectiveness of the different options for different countries. For example, it is observed that in Argentina, Bolivia, Chile, El Salvador, Paraguay, Suriname, Trinidad and Tobago, and Uruguay, the alternative of providing transfers to self-employed workers has a higher ratio, while doubling the value of social program transfers seems to have a better balance in Honduras, Guatemala, and Mexico. Transfers to the unemployed have a higher cost-benefit ratio in Brazil, Colombia, Costa Rica, Ecuador, Panama, Peru and the Dominican Republic. The option of rescheduling tax and social security payments, since it does not represent a fiscal cost in the medium and long term, is the alternative with the highest benefit ratio in all cases.

17 Results of the policies are not directly comparable with Lustig et al. (2020), since they employ a different set of policies. However, for Argentina the authors predict the potential effects of the Ingreso Familiar de Emergencia, which is close to our intervention 3 (expanding support for social programs), and we both find that around 3 p.p. of individuals would be lifted out of poverty. For Brazil, the Auxilio Emergencial is also close to our intervention 3. While the authors estimate a cushion of 4.7 p.p. of individuals lifted out of poverty, we estimate a reduction of 2.4 p.p. In Colombia, Familias en Acción, Fovenes en Acción, Colombia Mayor, Ingreso Solidario, Bogotá Solidaria are predicted to cushion 0.5 p.p out of poverty. These interventions are closer to our intervention 3, where we predict a cushion of 1 p.p. 
Table 3. Results of the simulation of interventions to cushion increasing impacts on the poor (extreme and moderate)

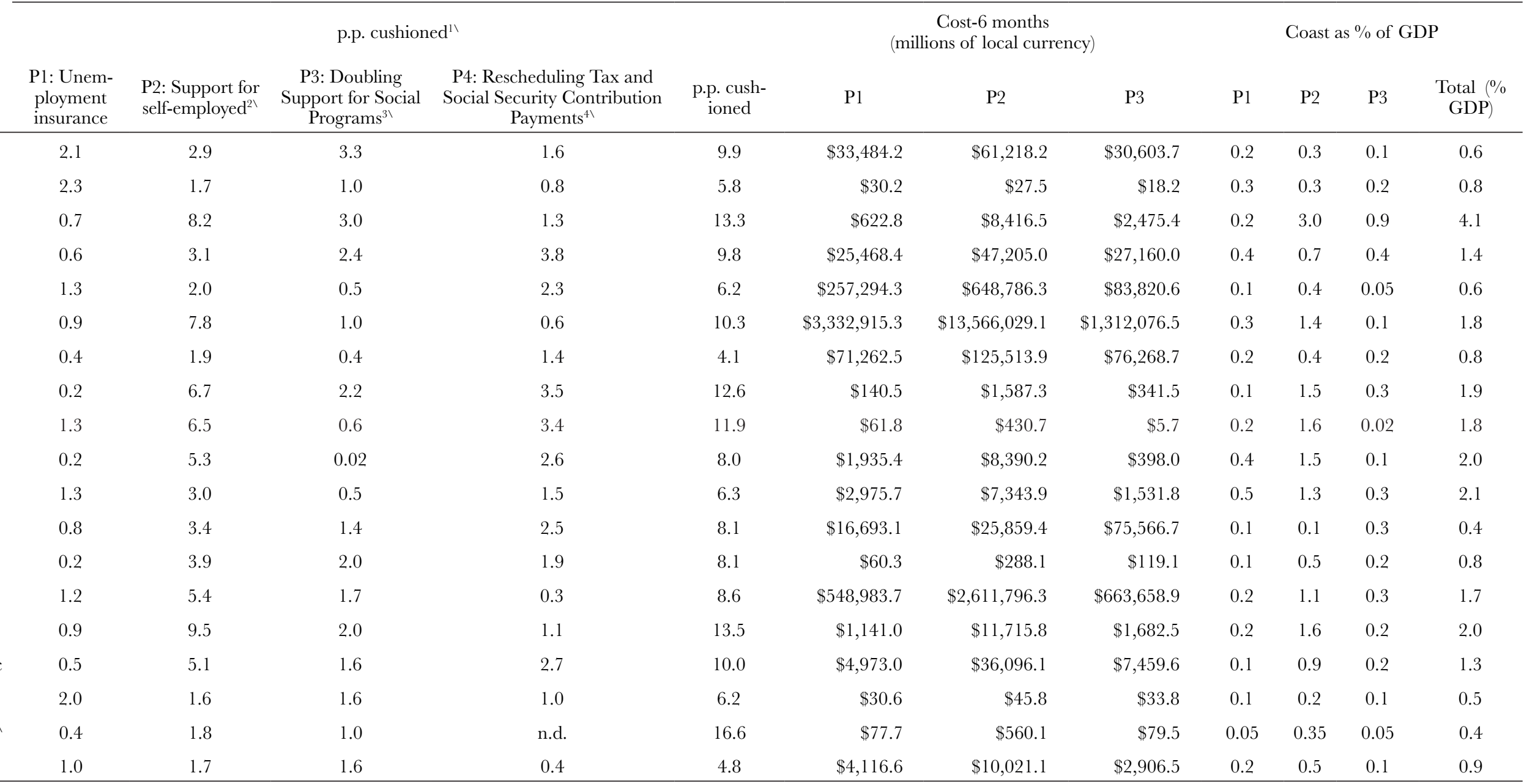

Uruguay

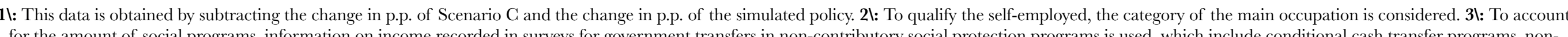

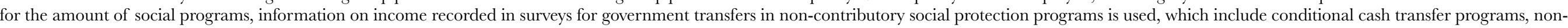

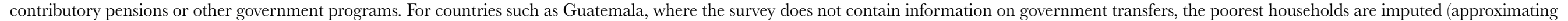

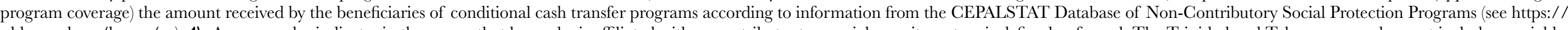

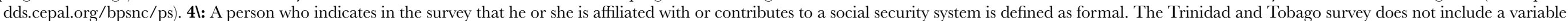

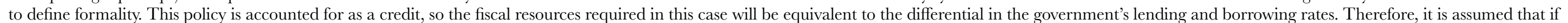
both are equivalent, and the administrative cost is charged at the lending rate, there will be no fiscal cost. 
Figure 8. Summary of the simulation of interventions to cushion impact on poverty and total cost (\% of GDP)

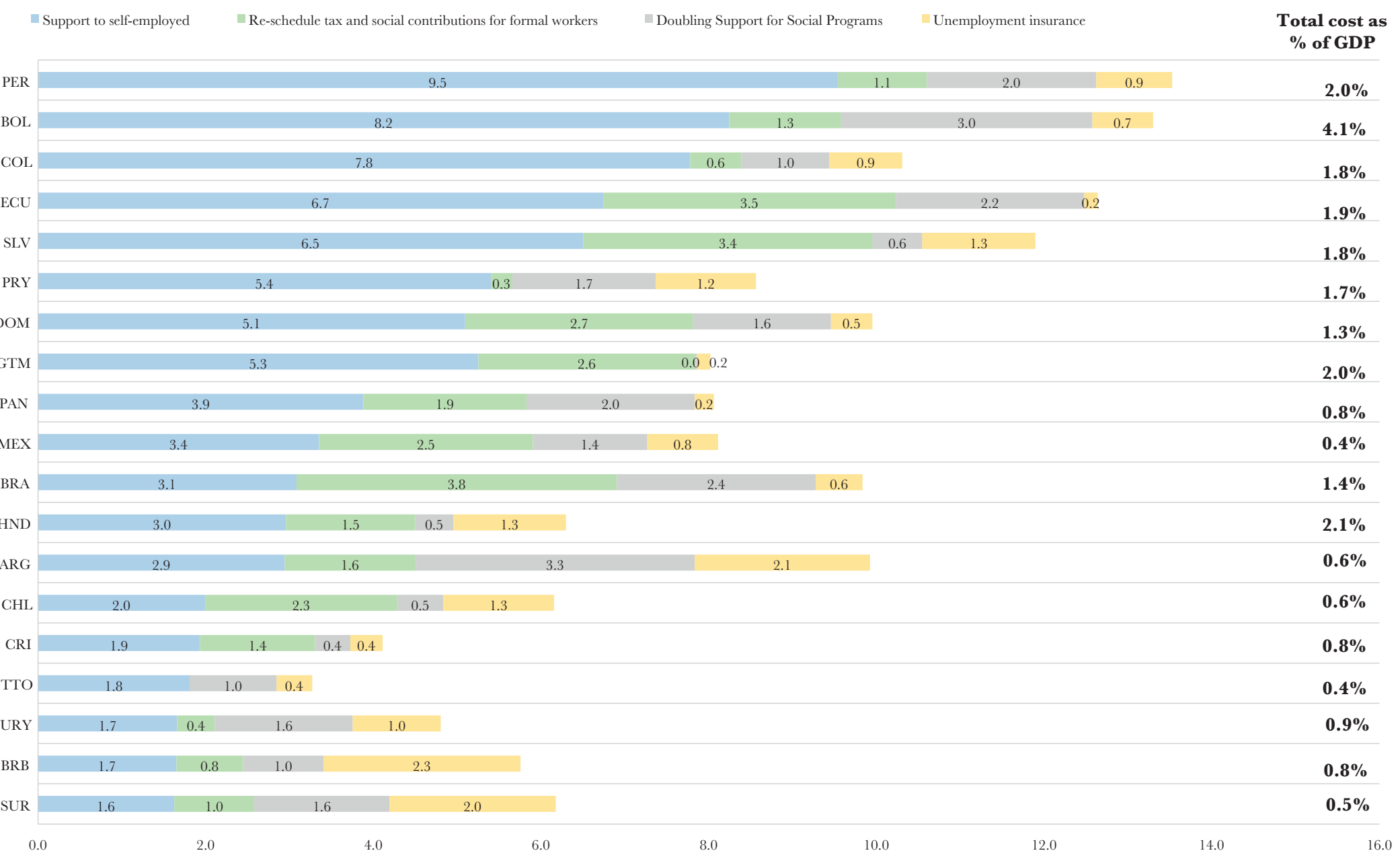

Source: Ditto. 
Table 4. Cost-Effectiveness Ratio of Policy Interventions

\begin{tabular}{|c|c|c|c|c|c|c|c|c|c|}
\hline \multirow[b]{3}{*}{$\begin{array}{l}\text { Argentina } \\
\text { (urban) }\end{array}$} & \multicolumn{3}{|c|}{ Buffer effect in p.p. } & \multicolumn{3}{|c|}{ Costs (in million dollars PPP) } & \multicolumn{3}{|c|}{ Cost-effectiveness ratio } \\
\hline & $\begin{array}{l}\text { P1: Unemploy- } \\
\text { ment insurance }\end{array}$ & $\begin{array}{l}\text { P2: Transfers to } \\
\text { self-employed } \\
\text { workers }\end{array}$ & $\begin{array}{c}\text { P3: } \\
\text { Double the } \\
\text { amount of social } \\
\text { program transfers }\end{array}$ & $\begin{array}{l}\text { P1: Unem- } \\
\text { ployment } \\
\text { insurance }\end{array}$ & $\begin{array}{l}\text { P2: Transfers to } \\
\text { self-employed } \\
\text { workers }\end{array}$ & $\begin{array}{c}\text { P3: } \\
\text { Double the } \\
\text { amount of social } \\
\text { program transfers }\end{array}$ & $\begin{array}{l}\text { P1: Unem- } \\
\text { ployment } \\
\text { insurance }\end{array}$ & $\begin{array}{l}\text { P2: Transfers to } \\
\text { self-employed } \\
\text { workers }\end{array}$ & $\begin{array}{c}\text { P3: } \\
\text { Double the amount of } \\
\text { social program transfers }\end{array}$ \\
\hline & 2.1 & 2.9 & 3.3 & $\$ 1,594.9$ & $\$ 2,915.8$ & $\$ 1,457.7$ & 763.0 & 990.8 & 437.8 \\
\hline Barbados & 2.3 & 1.7 & 1.0 & $\$ 14.2$ & $\$ 13.0$ & $\$ 8.6$ & 6.1 & 7.8 & 8.9 \\
\hline Bolivia & 0.7 & 8.2 & 3.0 & $\$ 225.0$ & $\$ 3,041.0$ & $\$ 894.4$ & 310.5 & 368.8 & 298.5 \\
\hline Brazil & 0.6 & 3.1 & 2.4 & $\$ 11,569.8$ & $\$ 21,444.3$ & $\$ 12,338.3$ & $20,706.2$ & $6,955.8$ & $5,206.6$ \\
\hline Chile & 1.3 & 2.0 & 0.5 & $\$ 625.6$ & $\$ 1,577.5$ & $\$ 203.8$ & 474.0 & 791.1 & 373.1 \\
\hline Colombia & 0.9 & 7.8 & 1.0 & $\$ 2,511.8$ & $\$ 10,223.9$ & $\$ 988.8$ & $2,888.5$ & $1,314.4$ & 944.5 \\
\hline Costa Rica & 0.4 & 1.9 & 0.4 & $\$ 202.7$ & $\$ 356.9$ & $\$ 216.9$ & 525.2 & 184.6 & 516.7 \\
\hline Ecuador & 0.2 & 6.7 & 2.2 & $\$ 264.1$ & $\$ 2,983.6$ & $\$ 641.9$ & $1,662.1$ & 442.5 & 285.5 \\
\hline El Salvador & 1.3 & 6.5 & 0.6 & $\$ 134.9$ & $\$ 940.1$ & $\$ 12.4$ & 99.9 & 144.5 & 21.0 \\
\hline Guatemala & 0.2 & 5.3 & 0.02 & $\$ 497.6$ & $\$ 2,157.3$ & $\$ 102.3$ & $3,101.1$ & 410.6 & $4,455.6$ \\
\hline Honduras & 1.3 & 3.0 & 0.5 & $\$ 288.5$ & $\$ 711.9$ & $\$ 148.5$ & 214.9 & 240.6 & 326.9 \\
\hline México & 0.8 & 3.4 & 1.4 & $\$ 1,829.0$ & $\$ 2,833.3$ & $\$ 8,279.5$ & $2,162.0$ & 845.0 & $6,070.0$ \\
\hline Panamá & 0.2 & 3.9 & 2.0 & $\$ 121.2$ & $\$ 579.2$ & $\$ 239.4$ & 533.5 & 149.2 & 119.3 \\
\hline Paraguay & 1.2 & 5.4 & 1.7 & $\$ 217.0$ & $\$ 1,032.3$ & $\$ 262.3$ & 181.6 & 191.1 & 153.4 \\
\hline Perú & 0.9 & 9.5 & 2.0 & $\$ 654.4$ & $\$ 6,719.4$ & $\$ 965.0$ & 723.8 & 704.3 & 477.6 \\
\hline $\begin{array}{l}\text { Dominican } \\
\text { Republic }\end{array}$ & 0.5 & 5.1 & 1.6 & $\$ 230.1$ & $\$ 1,670.1$ & $\$ 345.1$ & 464.9 & 327.7 & 210.2 \\
\hline Suriname & 2.0 & 1.6 & 1.6 & $\$ 12.6$ & $\$ 18.9$ & $\$ 13.9$ & 6.4 & 11.6 & 8.6 \\
\hline $\begin{array}{l}\text { Trinidad \& } \\
\text { Tobago }\end{array}$ & 0.4 & 1.8 & 1.0 & $\$ 18.3$ & $\$ 132.1$ & $\$ 18.8$ & 43.1 & 73.0 & 18.1 \\
\hline Uruguay & 1.0 & 1.7 & 1.6 & $\$ 161.9$ & $\$ 394.2$ & $\$ 114.3$ & 154.4 & 237.3 & 69.5 \\
\hline
\end{tabular}


It is also important to mention the relevance of distributional effects, which are not the focus of this analysis, but need to be considered when deciding which policy options to adopt. The distributional effects of the different interventions are not clear $e x$ ante and should be tested, but we could expect that interventions such as unemployment insurance or the expansion of existing social programs would target the poorest in society and, hence, be an instrument to reduce inequalities. Transfers to the self-employed would benefit workers who, contrary to the unemployed, are still active in the labor market, and while self-employed can overlap with the poorest population, not all of them are. Therefore, we can expect transfers to the self-employed to be potentially less equalizing compared to other interventions. The same is even more true for rescheduling tax and social security contributions payments, that would mostly target workers in the formal market, who are generally better off than the most vulnerable.

Finally, a caveat must be made as far at the implementation is concerned. The expected effects of these interventions might be reduced in case of policy failures, such as corruption, political tensions, dispersed governance, administrative silos and other factors threatening implementation. ${ }^{18}$

\section{Conclusion}

This document estimates the possible impact of the economic contraction associated with Covid-19 on the composition of social classes in Latin American and Caribbean countries. Using the most recent data on the drop in the growth rate and microdata from employment and household surveys, it is projected that the number of people living in poverty (extreme and moderate) would increase by up to 44 million in the region. On the other hand, a significant reduction of 52.2 million people who had previously reached the category of the consolidated middle-class is projected, and who, as a result of the impact of the pandemic, will move either into the vulnerable middle class or into poverty. Potentially, this recomposition of the population may affect demand patterns for some goods and services, among other effects.

A more detailed analysis of population flows between categories shows that the profile of those moving from the consolidated middle-class category to the vulnerable or poor middle class tends to be one of an urban population, of working age, and with a higher than average level of education. In contrast, the population that falls into the poverty category comes predominantly from rural areas and presents a younger profile - with higher proportions of the population between 0 and 15 years of age - with a greater representation of women, and a lower level of education.

In order to explore strategies for cushioning the economic impact of the pandemic, the potential of four types of interventions, as well as their costs, are compared. According to our analysis, the policy with the greatest benefit-cost ratio is the deferral of payroll taxes and social security contributions, because it represents a direct effect of increasing the level of liquidity for businesses that can be used to maintain employment and the value of wages, and with a proper design that defers their repayment into the future, their net fiscal cost can be close to zero. The other three alternatives of providing support to the unemployed, temporarily doubling the benefits of existing social programs, and transferring income to self-employed workers also generate a favorable benefit-cost ratio, with differences between countries. Assistance to the self-employed, for example, could be more beneficial in countries with high levels of informality. The expected benefits of the different interventions, however, might be hampered by recurring problems in policy implementation, such as corruption, political tensions, dispersed governance, administrative silos, or the vagaries of the political cycle. These problems need to be acknowledged and tackled to avoid policy failure in the implementation phase and achieve the desired effects.

18 Blofield, Giambruno, and Filgueira (2020), for example, find that in Chile and Costa Rica, delays were driven by political factors, and in Peru, by weaknesses in state capacity in reaching vulnerable populations. Brazil successfully achieved broad coverage, but effective implementation was initially slowed down by the executive's choice to centralize without using the existing policy infrastructure. 
Furthermore, our analysis focuses on the short term social costs of the pandemic, but it does not address other probable structural changes which might modify the sector composition of production or the demand for different types of skills, among others. These issues are part of the ongoing agenda that the phenomena will likely motivate in the future with the availability of up dated data sources.

The central conclusion derived from our analysis is that, although the pandemic will undoubtedly have a significant social cost in the region, there are public policy alternatives with reasonable fiscal cost within the reach of the countries, to counteract at least a part of the shortterm impacts and promote a reactivation with the greatest possible agility.

\section{References}

Blackman, A., Ibañez, A. M., Izquierdo, A., Keefer, P., Moreira, M., Schady, N., \& Serebrisky, T. (2020). La política pública frente al Covid-19: recomendaciones para América Latina y el Caribe. IDB.

Blofield, M., Giambruno, G., and Filgueira, F. (2020). Policy expansion in compressed time: Assessing the speed, breadth and sufficiency of post-COVID-19 social protection measures in 10 Latin American countries (N.o 235; Social Policy). ECLAC.

Bosch, M. and J. Esteban-Pretel. (2015). The labor market effects of introducing unemployment benefits in an economy with high informality, European Economic Review, 75: 1-17. https:// doi.org/10.1016/j.euroecorev.2014.10.010

Busso, M., Camacho, J., Messina, J., \& Montenegro, G. (2020). Covid-19: El desafío de garantizar ayuda a los trabajadores informarles y vulnerables. IDB.

CEPAL. (2020a). Informe sobre el impacto económico en América Latina y el Caribe de la enfermage por coronavirus (Covid-19). Santiago: Comisión Económica para América Latina y el Caribe.

CEPAL. (2020b). Enfrentar los efectos cada vez mayores del COVID-19 para una reactivación con igualdad: nuevas proyecciones. Santiago: Comisión Económica para América Latina y el Caribe.

Goñi, E. J., H. López and L. Servén. (2011)."Fiscal Redistribution and Income Inequality in Latin America", World Development, 39(9): 1558-1569. https://doi.org/10.1016/j.worlddev.2011.04.025

IDB. (2020). Como Proteger los Ingresos y los Empleos: posibles respuestas al impacto del coronavirus (COVID.19) en los mercados laborales de América Latina y el Caribe.

IDB. (2020b). CAN: Covid-19 impact in the region's economies.

IDB. (2020c). CGB: Covid-19 impact in the region's economies.

IDB. (2020d). CID: Covid-19 impact in the region's economies.

IDB. (2020e). CAN: Covid-19 impact in the region's economies.

IDB. (2020f). "Impacto del COVID19 en el comercio exterior, las inversiones y la integración en AL" http://conexionintal.iadb.org/descargas/index.php?file=Newsletter20INTAL20Comercio20y20Covid-1920Num4\&origen=conexion INTAL

IDB. (2020g). Del confinamiento a la reapertura: Consideraciones estratégicas para el reinicio de las actividades en América Latina y el Caribe en el marco de la Covid-19. 
IDB. (2020h). La política pública frente al Covid-19: Recomendaciones para América Latina y el Caribe.

IDB. (2020i). LAC Post Covid-19: Challenges and Opportunities for the Caribbean Countries.

IDB. (2020j). ALC Post Covid-19: Retos y oportunidades para Countryes de Centroamérica, Haití, Mexico, Panama, y Dominican Republic.

IDB. (2020k) ALC Post Covid-19: Retos y oportunidades para Countryes de la Región Andina.

IDB. (2020l) ALC Post Covid-19: Retos y oportunidades para Countryes del Cono Sur.

IDB. (2020m) Salir del túnel pandémico con crecimiento y equidad: Una estrategia para un nuevo compacto social en América Latina y el Caribe.

IDB. (2020n). IDBG Strategic Selectivity Framework for 2021-2022 Programming Cycle, presentation to the Board of Directors, August 2020.

IDB (2020o). Cómo crear una nueva normalidad con equidad e inclusión. Informe económico de México, Centroamérica, y República Dominicana. Editores Marta Ruiz-Arranz y Arnoldo López Marmolejo. Banco Interamericano de Desarrollo. Washington, D.C.: Estados Unidos.

IDB. (forthcoming) Labor Market Sector framework document.

ILO. (2020). https://www.ilo.org/wcmsp5/groups/public/---dgreports/---dcomm/documents/briefingnote/wcms 745963.pdf

ILO. (2019). Panorama Laboral Temático 5: Womanes en el mundo del trabajo. Retos pendientes hacia una efectiva equidad en América Latina y el Caribe. Lima: OIT / Oficina Regional para América Latina y el Caribe.

IMF (2020). https://blogs.imf.org/2020/06/26/outlook-for-latin-america-and-the-caribbean-an-intensifying-pandemic/

IMF. (2020). Pespectivas de la Economía Mundial, junio 2020. Fondo Monetario Internacional.

IMF. (2003). 2003 Article IV Consultation with Brazil. International Monerary Fund.

Loayza, N. V., 2020. https://ideas.repec.org/p/wbk/wbkrpb/148535.html" Costs and TradeOffs in the Fight Against the Covid-19 Pandemic: A Developing Country Perspective "https://ideas.repec.org/s/wbk/wbkrpb.html" Research and Policy Briefs 148535, The World Bank.

Loayza, N.V., Servén, L. and Sugawara, N. (2013). "Informality in Latin America and the Caribbean", Policy Research Working Papers, The World Bank.

Lustig, N., V. Martínez, F. Sanz, and S. Younger (2020). The impact of COVID-19 lockdowns and expanded social assistance on inequality, poverty and mobility in Argentina, Brazil, Colombia and Mexico. Tulane University, CEQ Institute.

Meghir, C., R. Narita, and J. M. Robin. 2015. "Wages and Informality in Developing Countries." American Economic Review, 105 (4): 1509-46. DOI: 10.1257/aer.20121110

OECD (2020a) https://www.oecd.org/coronavirus/policy-responses/covid-19-in-latin-america-and-the-caribbean-regional-socio-economic-implications-and-policy-priorities-93a64fde/

OECD. (2020b). Covid-19 in Latin America and the Caribbean: An overview of government responses to the crisis. 
Ulyssea, G. (2018). Firms, informality, and development: Theory and evidence from Brazil. American Economic Review, 108(8): 2015-47. DOI: 10.1257/aer.20141745

UN. (2020). Policy Brief: The Impact of Covid-19 on Latin America and the Caribbean. United Nations.

Unicef (2020). https://www.unicef.org/lac/en/press-releases/covid-19-number-children-living-household-poverty-soar-86-million

Végh, G., G., Vuletin, D., Riera-Crichton, J. P., Puig, J. A., Camarena, L., Galeano, L. Morano, L. Venturi. (2019). ¿Cómo afecta el ciclo económico a los indicadores sociales en América Latina y el Caribe?: Cuando los sueños enfrentan la realidad? Washington, DC.: Banco Mundial.

World Bank. (2020). La Economía en los Tiempos del Covid-19.

\section{Annex}

Table A.1 Household survey sources

\begin{tabular}{|c|c|}
\hline Countries & Source of information \\
\hline Argentina $^{1 \backslash}$ & Permanent Household Survey 2019 \\
\hline Barbados & Barbados Survey of Living Conditions 2016 \\
\hline Bolivia & Household Survey 2018 \\
\hline Brazil & $\begin{array}{l}\text { National Research by Amostra de Domicílios Contínua } \\
2018\end{array}$ \\
\hline Chile & National Socioeconomic Characterization Survey 2017 \\
\hline Colombia & Large Integrated Household Survey 2018 \\
\hline Costa Rica & National Household Survey 2018 \\
\hline Ecuador & $\begin{array}{l}\text { National Survey of Employment, Unemployment and } \\
\text { Underemployment } 2018\end{array}$ \\
\hline El Salvador & Multipurpose Household Survey 2019 \\
\hline Guatemala & National Survey of Employment and Income 2018 \\
\hline Honduras & Permanent Multipurpose Household Survey 2018 \\
\hline Jamaica & Jamaica Survey of Living Conditions 2015 \\
\hline Mexico & $\begin{array}{l}\text { National Household Income and Expenditure Survey } \\
2018\end{array}$ \\
\hline Panama & Permanent Household Survey 2017 \\
\hline Paraguay & Permanent Household Survey Continues 2018 \\
\hline Peru & National Household Survey 2018 \\
\hline Republican Sunday & 2017 National Continuing Workforce Survey \\
\hline Suriname & Suriname Survey of Living Conditions 2016-2017 \\
\hline Trinidad \& Tobago & Continuous Sample Survey of Population 2015 \\
\hline Uruguay & Continuous Household Survey 2019 \\
\hline
\end{tabular}

1\: In Argentina the EPH has urban coverage only. 
Table A. 2. Periods chosen for the elaboration of Scenario A

\begin{tabular}{lcc}
\hline \multicolumn{1}{c}{ Country } & $\begin{array}{c}\text { Change in rate of } \\
\text { change of real GDP }\end{array}$ & $\begin{array}{c}\text { Annualized change associated } \\
\text { with income in }\end{array}$ \\
\hline Argentina ${ }^{1}$ & $2013-2014$ & $2013-2014$ \\
Barbados & $2008-2009$ & $2008-2009$ \\
Bolivia & $1998-1999$ & $1999-2000$ \\
Brazil & $2002-2003$ & $2002-2004$ \\
Chile & $2009-2013$ & $2011-2013$ \\
Colombia & $1998-1999$ & $1998-1999$ \\
Costa Rica & $2008-2009$ & $2009-2010$ \\
Ecuador & $2008-2009$ & $2008-2009$ \\
El Salvador & $2008-2009$ & $2007-2009$ \\
Guatemala & $2008-2009$ & $2006-2010$ \\
Honduras & $2008-2009$ & $2007-2008$ \\
Jamaica & $2009-2010$ & $2009-2013$ \\
Mexico & $2008-2009$ & $2008-2009$ \\
Panama & $2008-2009$ & $2009-2010$ \\
Paraguay & $2008-2009$ & $2007-2009$ \\
Peru & $2003-2004$ & $2003-2004$ \\
Republican Sunday & $2008-2009$ & $2009-2010$ \\
Suriname & $2014-2015$ & $2014-2015$ \\
Trinidad and Tobago & $2008-2009$ & $2008-2010$ \\
Uruguay & $2001-2002$ & $2001-2002$ \\
\hline
\end{tabular}

Source: Selection of episodes based on the identification of economic contractions in previous years in which there is a simultaneous reduction in real wages and real per capita GDP. Note that in some cases, such as Argentina, Chile and Suriname, significant drops in GDP are observed in periods after 2008-2009, while in others, such as Brazil, the selection of the reference episode identified is one in which the country registered a balance of payments crisis that generated a significant economic deceleration - with considerable levels of inflation - and growth rates close to zero. On the other hand, in El Salvador, Guatemala, Honduras and Paraguay, the episode of reduction in GDP is 2008-2009, but there are no successive household surveys for the same years. In these cases, information on changes in salaries over a longer or shorter period is used, depending on the availability of surveys, under the condition that the period includes the years 2008-2009. For these periods, the annual change in real wages between the two available surveys is calculated, and the result is used to compare with the change in GDP for 2008-2009. 
Table A.3. Distribution of the population according to social class assuming a decrease in labor and non-labor income

\begin{tabular}{|c|c|c|c|c|c|c|c|c|c|c|c|}
\hline \multirow{2}{*}{ Country } & \multicolumn{5}{|c|}{ Base Scenario $^{1 \backslash}$} & \multicolumn{3}{|c|}{ Extreme poor } & \multicolumn{3}{|c|}{ Moderate poor } \\
\hline & $\begin{array}{l}\text { Extreme } \\
\text { poor }\end{array}$ & $\begin{array}{l}\text { Moderate } \\
\text { poor }\end{array}$ & $\begin{array}{l}\text { Vulnerable } \\
\text { middle-class }\end{array}$ & $\begin{array}{l}\text { Consolidated } \\
\text { middle-class }\end{array}$ & Rich & Scenario A & Scenario B & Scenario $\mathrm{C}$ & Scenario A & Scenario B & Scenario $\mathrm{G}$ \\
\hline Argentina $^{1 \backslash}$ & 9.1 & 9.6 & 36.9 & 42.3 & 2.1 & 9.9 & 10.6 & 12.1 & 10.2 & 10.7 & 12.3 \\
\hline Barbados & 16.8 & 9.8 & 32.1 & 38.6 & 2.7 & 17.8 & 19.1 & 20.2 & 10.7 & 10.5 & 11.5 \\
\hline Bolivia & 14.3 & 11.5 & 41.1 & 32.5 & 0.6 & 14.4 & 16.9 & 19.8 & 11.7 & 12.9 & 15.9 \\
\hline Brazil & 9.6 & 9.3 & 31.7 & 43.7 & 5.7 & 9.7 & 12.0 & 14.7 & 9.4 & 10.6 & 12.4 \\
\hline Chile & 3.1 & 4.5 & 34.4 & 51.5 & 6.5 & 3.2 & 3.8 & 4.8 & 4.6 & 6.1 & 8.3 \\
\hline Colombia & 14.6 & 12.4 & 33.8 & 34.6 & 4.5 & 16.4 & 16.0 & 17.5 & 13.8 & 12.9 & 14.0 \\
\hline Costa Rica & 6.4 & 8.5 & 35.5 & 44.4 & 5.3 & 6.6 & 7.0 & 7.9 & 8.6 & 9.0 & 9.7 \\
\hline Ecuador & 10.6 & 12.0 & 39.7 & 35.6 & 2.0 & 11.2 & 14.0 & 17.8 & 13.2 & 14.6 & 16.6 \\
\hline El Salvador & 11.7 & 16.7 & 48.6 & 22.5 & 0.4 & 12.9 & 16.9 & 19.0 & 18.0 & 21.5 & 21.7 \\
\hline Guatemala & 31.5 & 20.1 & 33.2 & 14.9 & 0.3 & 34.8 & 36.0 & 41.1 & 19.1 & 19.9 & 20.4 \\
\hline Honduras & 36.1 & 18.5 & 31.2 & 13.7 & 0.5 & 36.8 & 38.0 & 39.9 & 18.3 & 18.7 & 18.8 \\
\hline Jamaica & & 19.5 & 50.6 & 29.6 & 0.3 & & & & 21.3 & 23.7 & 29.3 \\
\hline Mexico & 15.8 & 20.0 & 42.2 & 21.1 & 0.7 & 17.9 & 19.1 & 20.5 & 22.0 & 22.9 & 24.1 \\
\hline Panama & 8.1 & 7.6 & 30.4 & 48.6 & 5.3 & 9.2 & 9.9 & 12.8 & 8.9 & 9.1 & 10.6 \\
\hline Paraguay & 9.3 & 10.3 & 36.8 & 40.7 & 2.9 & 10.4 & 10.2 & 11.1 & 10.6 & 10.9 & 11.6 \\
\hline Peru & 9.2 & 12.0 & 42.6 & 34.6 & 1.6 & 9.6 & 11.5 & 15.1 & 12.5 & 13.7 & 16.2 \\
\hline Republican Sunday & 6.5 & 11.4 & 46.5 & 34.2 & 1.5 & 7.0 & 8.5 & 11.3 & 11.7 & 13.3 & 15.5 \\
\hline Suriname & 12.4 & 8.8 & 36.5 & 40.1 & 2.2 & 13.1 & 13.4 & 14.5 & 10.8 & 11.6 & 11.4 \\
\hline Trinidad \& Tobago & 4.1 & 7.9 & 38.2 & 48.4 & 1.4 & 4.5 & 4.4 & 5.7 & 8.4 & 8.2 & 7.6 \\
\hline Uruguay & 1.3 & 2.9 & 24.6 & 65.7 & 5.6 & 1.8 & 1.5 & 1.8 & 4.2 & 3.5 & 4.2 \\
\hline LAC Average & 12.1 & 11.7 & 37.3 & 36.9 & 2.6 & 13.4 & 14.6 & 16.8 & 13.9 & 14.6 & 15.6 \\
\hline LA Average & 12.3 & 11.7 & 36.8 & 36.3 & 2.8 & 13.2 & 14.5 & 16.7 & 12.3 & 13.1 & 14.5 \\
\hline Caribbean Average & 11.1 & 11.5 & 39.3 & 39.2 & 1.6 & 14.2 & 15.2 & 17.4 & 20.1 & 20.4 & 20.1 \\
\hline
\end{tabular}


Table A.3 (continued) Distribution of the population according to social class assuming a decrease in labor and non-labor income

\begin{tabular}{|c|c|c|c|c|c|c|c|c|c|}
\hline \multirow{2}{*}{ Country } & \multicolumn{3}{|c|}{ Vulnerable middle class } & \multicolumn{3}{|c|}{ Consolidated middle class } & \multicolumn{3}{|c|}{ Rich } \\
\hline & Scenario A & Scenario B & Scenario $\mathrm{C}$ & Scenario A & Scenario B & Scenario $\mathrm{C}$ & Scenario A & Scenario B & Scenario \\
\hline Argentina $^{11}$ & 38.7 & 40.0 & 41.1 & 39.4 & 37.0 & 33.3 & 1.8 & 1.8 & 1.2 \\
\hline Barbados & 33.9 & 34.8 & 35.1 & 35.5 & 33.9 & 32.0 & 2.2 & 1.7 & 1.3 \\
\hline Bolivia & 40.9 & 42.1 & 41.7 & 32.3 & 27.8 & 22.4 & 0.6 & 0.4 & 0.2 \\
\hline Brazil & 31.8 & 35.8 & 38.7 & 43.4 & 37.0 & 30.9 & 5.6 & 4.6 & 3.4 \\
\hline Chile & 34.7 & 38.7 & 42.9 & 51.2 & 46.0 & 39.7 & 6.4 & 5.5 & 4.3 \\
\hline Colombia & 33.9 & 34.3 & 34.1 & 32.0 & 32.7 & 30.7 & 4.0 & 4.1 & 3.7 \\
\hline Costa Rica & 35.9 & 36.7 & 37.2 & 43.9 & 42.6 & 40.9 & 5.1 & 4.7 & 4.3 \\
\hline Ecuador & 39.4 & 40.7 & 40.8 & 34.3 & 29.3 & 23.9 & 1.9 & 1.4 & 0.9 \\
\hline El Salvador & 48.6 & 45.8 & 44.9 & 20.1 & 15.6 & 14.3 & 0.3 & 0.2 & 0.2 \\
\hline Guatemala & 31.8 & 31.1 & 28.5 & 13.9 & 12.6 & 9.8 & 0.3 & 0.2 & 0.1 \\
\hline Honduras & 30.9 & 30.4 & 29.5 & 13.5 & 12.5 & 11.3 & 0.5 & 0.4 & 0.4 \\
\hline Jamaica & 50.4 & 51.3 & 49.8 & 27.9 & 24.6 & 20.7 & 0.3 & 0.3 & 0.2 \\
\hline Mexico & 41.9 & 41.3 & 40.6 & 17.7 & 16.2 & 14.5 & 0.4 & 0.4 & 0.2 \\
\hline Panama & 32.3 & 33.1 & 35.9 & 44.8 & 43.8 & 37.7 & 4.8 & 4.2 & 3.0 \\
\hline Paraguay & 37.0 & 37.9 & 39.0 & 39.2 & 38.3 & 35.9 & 2.8 & 2.7 & 2.5 \\
\hline Peru & 42.9 & 44.1 & 44.2 & 33.5 & 29.5 & 23.6 & 1.5 & 1.2 & 0.9 \\
\hline Republican Sunday & 47.5 & 47.5 & 47.5 & 32.6 & 29.6 & 24.9 & 1.3 & 1.2 & 0.8 \\
\hline Suriname & 36.9 & 36.9 & 38.1 & 37.3 & 36.4 & 34.5 & 1.9 & 1.7 & 1.6 \\
\hline Trinidad \& Tobago & 39.6 & 39.8 & 42.0 & 46.2 & 46.3 & 43.8 & 1.3 & 1.3 & 1.0 \\
\hline Uruguay & 29.5 & 26.8 & 29.6 & 60.7 & 63.5 & 60.6 & 3.8 & 4.7 & 3.7 \\
\hline LAC Average & 36.8 & 37.1 & 37.6 & 33.6 & 31.5 & 28.2 & 2.3 & 2.1 & 1.7 \\
\hline LA Average & 37.3 & 37.9 & 38.5 & 34.5 & 32.1 & 28.4 & 2.6 & 2.3 & 1.9 \\
\hline Caribbean Average & 34.6 & 34.0 & 34.0 & 29.9 & 29.2 & 27.6 & 1.3 & 1.2 & 1.0 \\
\hline
\end{tabular}

11: The following definitions are used for the classification of the population according to socioeconomic level, following the definitions of the IDB Sociometer: the poor class has an income of US $\$ 3.1$ to US $\$ 5$; the



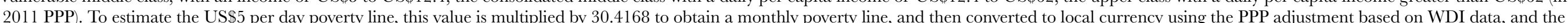
value is updated using the national CPI for the survey year.

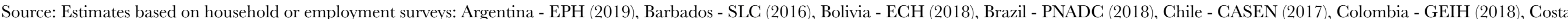
Rica - ENAHO (2018), Ecuador - ENEMDU (2018), El Salvador - EHPM (2019), Guatemala - ENEI (2018), Honduras - EPHPM - (2018), Jamaica - SLC (2015), Mexico - ENIGH (2018), Panama - EPM (2017),

Paraguay - EPHC (2018), Peru - ENAHO (2018), Dominican Republic - ENCFT (2017), Suriname - SLC (2017), Trinidad and Tobago - CSSP (2015), Uruguay - ECH (2019). 
Table A.4. Changes in percentage points in the distribution of the population according to social class assuming a decrease in labor and non-labor income

\begin{tabular}{|c|c|c|c|c|c|c|c|c|c|}
\hline \multirow{2}{*}{ Country } & \multicolumn{3}{|c|}{ Extreme poverty } & \multicolumn{3}{|c|}{ Moderate poverty } & \multicolumn{3}{|c|}{ Vulnerable middle class } \\
\hline & Scenario A & Scenario B & Scenario C & Scenario A & Scenario B & Scenario C & Scenario A & Scenario B & Scenario $\mathrm{C}$ \\
\hline Argentina (urban) & 0.8 & 1.5 & 3.0 & 0.6 & 1.1 & 2.7 & 1.8 & 3.1 & 4.2 \\
\hline Barbados & 1.0 & 2.3 & 3.4 & 0.9 & 0.7 & 1.7 & 1.8 & 2.7 & 3.0 \\
\hline Bolivia & 0.1 & 2.6 & 5.5 & 0.2 & 1.4 & 4.3 & -0.2 & 1.0 & 0.6 \\
\hline Brazil & 0.1 & 2.4 & 5.1 & 0.1 & 1.3 & 3.0 & 0.1 & 4.2 & 7.0 \\
\hline Chile & 0.1 & 0.7 & 1.7 & 0.1 & 1.5 & 3.8 & 0.3 & 4.3 & 8.5 \\
\hline Colombia & 1.7 & 1.4 & 2.9 & 1.4 & 0.5 & 1.6 & 0.1 & 0.5 & 0.2 \\
\hline Costa Rica & 0.2 & 0.7 & 1.5 & 0.1 & 0.5 & 1.3 & 0.4 & 1.1 & 1.7 \\
\hline Ecuador & 0.6 & 3.3 & 7.1 & 1.1 & 2.6 & 4.5 & -0.3 & 1.0 & 1.1 \\
\hline El Salvador & 1.2 & 5.2 & 7.2 & 1.3 & 4.8 & 5.0 & -0.1 & -2.9 & -3.8 \\
\hline Guatemala & 3.4 & 4.6 & 9.6 & -1.0 & -0.2 & 0.3 & -1.4 & -2.0 & -4.6 \\
\hline Honduras & 0.7 & 1.9 & 3.8 & -0.2 & 0.2 & 0.3 & -0.3 & -0.9 & -1.7 \\
\hline Jamaica & & & & 1.8 & 4.2 & 9.8 & -0.1 & 0.7 & -0.8 \\
\hline Mexico & 2.0 & 3.2 & 4.7 & 2.0 & 2.9 & 4.1 & -0.3 & -0.8 & -1.6 \\
\hline Panama & 1.0 & 1.7 & 4.7 & 1.3 & 1.5 & 3.0 & 1.9 & 2.7 & 5.5 \\
\hline Paraguay & 1.1 & 0.9 & 1.8 & 0.3 & 0.6 & 1.3 & 0.2 & 1.2 & 2.2 \\
\hline Peru & 0.4 & 2.3 & 5.9 & 0.5 & 1.7 & 4.2 & 0.3 & 1.5 & 1.6 \\
\hline Dominican Republic & 0.5 & 2.0 & 4.8 & 0.3 & 1.9 & 4.1 & 1.0 & 1.1 & 1.1 \\
\hline Suriname & 0.6 & 1.0 & 2.1 & 2.0 & 2.8 & 2.6 & 0.4 & 0.4 & 1.6 \\
\hline Trinidad and Tobago & 0.4 & 0.4 & 1.6 & 0.5 & 0.3 & -0.3 & 1.4 & 1.5 & 3.7 \\
\hline Uruguay & 0.5 & 0.2 & 0.5 & 1.3 & 0.7 & 1.4 & 4.9 & 2.2 & 5.0 \\
\hline LAC Average & 0.9 & 2.0 & 4.1 & 0.7 & 1.6 & 2.9 & 0.6 & 1.1 & 1.7 \\
\hline LA Average & 0.9 & 2.2 & 4.4 & 0.6 & 1.4 & 2.8 & 0.5 & 1.1 & 1.7 \\
\hline Caribbean Average & 0.7 & 1.2 & 2.4 & 1.3 & 2.0 & 3.4 & 0.9 & 1.3 & 1.9 \\
\hline
\end{tabular}


Table A.4 (continued) Changes in percentage points in the distribution of the population according to social class assuming a decrease in labor and non-labor income

\begin{tabular}{|c|c|c|c|c|c|c|}
\hline \multirow{2}{*}{ Country } & \multicolumn{3}{|c|}{ Consolidated middle class } & \multicolumn{3}{|c|}{ Rich } \\
\hline & Scenario A & Scenario B & Scenario $\mathrm{C}$ & Scenario A & Scenario B & Scenario \\
\hline Argentina (urban) & -2.9 & -5.3 & -9.1 & -0.3 & -0.4 & -0.9 \\
\hline Barbados & -3.1 & -4.7 & -6.7 & -0.5 & -0.9 & -1.4 \\
\hline Bolivia & -0.2 & -4.7 & -10.1 & -0.01 & -0.2 & -0.4 \\
\hline Brazil & -0.3 & -6.7 & -12.9 & -0.1 & -1.1 & -2.3 \\
\hline Chile & -0.3 & -5.5 & -11.8 & -0.1 & -1.0 & -2.2 \\
\hline Colombia & -2.7 & -2.0 & -3.9 & -0.6 & -0.4 & -0.9 \\
\hline Costa Rica & -0.5 & -1.7 & -3.5 & -0.2 & -0.6 & -0.9 \\
\hline Ecuador & -1.3 & -6.4 & -11.7 & -0.1 & -0.6 & -1.1 \\
\hline El Salvador & -2.4 & -6.9 & -8.2 & -0.004 & -0.2 & -0.2 \\
\hline Guatemala & -1.0 & -2.3 & -5.1 & -0.01 & -0.1 & -0.2 \\
\hline Honduras & -0.2 & -1.2 & -2.4 & 0.0 & -0.1 & -0.1 \\
\hline Jamaica & -1.7 & -4.9 & -8.9 & 0.00 & -0.01 & -0.1 \\
\hline Mexico & -3.5 & -4.9 & -6.7 & -0.3 & -0.4 & -0.5 \\
\hline Panama & -3.8 & -4.8 & -10.9 & -0.5 & -1.1 & -2.3 \\
\hline Paraguay & -1.5 & -2.4 & -4.8 & -0.1 & -0.2 & -0.5 \\
\hline Peru & -1.1 & -5.1 & -11.0 & -0.1 & -0.4 & -0.7 \\
\hline Dominican Republic & -1.7 & -4.7 & -9.3 & -0.1 & -0.3 & -0.6 \\
\hline Suriname & -2.8 & -3.7 & -5.6 & -0.3 & -0.4 & -0.6 \\
\hline Trinidad and Tobago & -2.2 & -2.1 & -4.7 & -0.1 & -0.1 & -0.4 \\
\hline Uruguay & -5.0 & -2.2 & -5.1 & -1.8 & -0.9 & -1.9 \\
\hline LAC Average & -1.9 & -4.1 & -7.6 & -0.3 & -0.5 & -0.9 \\
\hline LA Average & -1.8 & -4.2 & -7.9 & -0.3 & -0.5 & -1.0 \\
\hline Caribbean Average & -2.4 & -3.9 & -6.4 & -0.2 & -0.4 & -0.6 \\
\hline
\end{tabular}

Source: Estimates from households or employment surveys : Argentina - EPH (2019), Barbados - SLC (2016), Bolivia - ECH (2018), Brazil - PNADC (2018), Chile - CASEN (2017), Colombia - GEIH (2018), Costa Rica -


(2018), Peru - ENAHO (2018), Dominican Republic - ENCFT (2017), Suriname - SLC (2017), Trinidad and Tobago - CSSP (2015), Uruguay - ECH (2019). 
Table A.5. Changes in the number of people according to social class assuming a decrease in labor and non-labor income

\begin{tabular}{|c|c|c|c|c|c|c|c|c|c|}
\hline \multirow{2}{*}{ Country } & \multicolumn{3}{|c|}{ Extreme poverty } & \multicolumn{3}{|c|}{ Moderate poverty } & \multicolumn{3}{|c|}{ Vulnerable middle class } \\
\hline & Scenario A & Scenario B & Scenario $\mathrm{C}$ & Scenario A & Scenario B & Scenario $\mathrm{C}$ & Scenario A & Scenario B & Scenario $\mathrm{C}$ \\
\hline Argentina (urban) & 229300 & 411979 & 856261 & 168725 & 322885 & 779762 & 510545 & 877966 & 1189959 \\
\hline Barbados & 2046 & 4768 & 7123 & 1809 & 1450 & 3508 & 3811 & 5712 & 6336 \\
\hline Bolivia & 16649 & 291326 & 627051 & 25269 & 153339 & 492789 & -19022 & 114911 & 63661 \\
\hline Brazil & 287066 & 4885819 & 10473884 & 227204 & 2621139 & 6226398 & 242879 & 8513799 & 14339417 \\
\hline Chile & 9483 & 122845 & 306570 & 9596 & 273318 & 668917 & 51387 & 761025 & 1515107 \\
\hline Colombia & 845152 & 694632 & 1399360 & 680221 & 237285 & 778578 & 39512 & 223304 & 114017 \\
\hline Costa Rica & 8974 & 33222 & 74576 & 7467 & 27031 & 63539 & 17559 & 56935 & 85037 \\
\hline Ecuador & 101991 & 569574 & 1220459 & 195125 & 447226 & 776385 & -57119 & 171075 & 191158 \\
\hline El Salvador & 80821 & 348978 & 484578 & 88457 & 319933 & 332265 & -6423 & -191839 & -251740 \\
\hline Guatemala & 591657 & 800215 & 1682645 & -178922 & -35899 & 48759 & -243274 & -354385 & -810631 \\
\hline Honduras & 67170 & 172105 & 345173 & -19435 & 17835 & 30420 & -30862 & -80034 & -155062 \\
\hline Jamaica & & & & 48788 & 114324 & 266477 & -3161 & 20361 & -21195 \\
\hline Mexico & 2596973 & 4099063 & 5974439 & 2577163 & 3706911 & 5199033 & -330988 & -1078846 & -2027153 \\
\hline Panama & 41278 & 70182 & 189917 & 54489 & 60168 & 121383 & 79136 & 108243 & 226165 \\
\hline Paraguay & 76648 & 63333 & 125284 & 19520 & 40980 & 88189 & 15427 & 80569 & 153140 \\
\hline Peru & 147356 & 779273 & 1975767 & 153824 & 576118 & 1393093 & 96747 & 490144 & 529300 \\
\hline Dominican Republic & 49463 & 202046 & 487708 & 30174 & 196792 & 419833 & 102005 & 108203 & 107651 \\
\hline Suriname & 3204 & 4864 & 10233 & 10027 & 13833 & 12841 & 2088 & 1947 & 7776 \\
\hline Trinidad \& Tobago & 5509 & 5196 & 22476 & 6824 & 4508 & -3694 & 19032 & 20597 & 50774 \\
\hline Uruguay & 19030 & 8317 & 19030 & 45976 & 23257 & 47856 & 172921 & 78083 & 176469 \\
\hline LAG Average & 5179771 & 13567739 & 26282533 & 4152299 & 9122434 & 17746333 & 662202 & 9927771 & 15490186 \\
\hline LA Average & 5169011 & 13552910 & 26242701 & 4084852 & 8988320 & 17467199 & 640431 & 9879153 & 15446495 \\
\hline Caribbean Average & 10759 & 14829 & 39832 & 67447 & 134114 & 279133 & 21771 & 48619 & 43690 \\
\hline
\end{tabular}


Table A.5 (continued) Changes in the number of people according to social class assuming a decrease in labor and non-labor income

\begin{tabular}{|c|c|c|c|c|c|c|}
\hline \multirow{2}{*}{ Country } & \multicolumn{3}{|c|}{ Consolidated middle class } & \multicolumn{3}{|c|}{ Rich } \\
\hline & Scenario A & Scenario B & Scenario $\mathrm{C}$ & Scenario A & Scenario B & Scenario $\mathrm{C}$ \\
\hline Argentina (urban) & -836611 & -1513242 & -2571081 & -71960 & -99588 & -254902 \\
\hline Barbados & -6606 & -9980 & -14076 & -1059 & -1951 & -2891 \\
\hline Bolivia & -22260 & -538132 & -1143470 & -637 & -21444 & -40031 \\
\hline Brazil & -637725 & -13762241 & -26292857 & -119424 & -2258516 & -4746842 \\
\hline Chile & -55272 & -980302 & -2106323 & -15193 & -176886 & -384271 \\
\hline Colombia & -1291322 & -952696 & -1878660 & -273563 & -202526 & -413294 \\
\hline Costa Rica & -25482 & -87550 & -176264 & -8517 & -29638 & -46888 \\
\hline Ecuador & -218664 & -1086076 & -2000204 & -21333 & -101799 & -187798 \\
\hline El Salvador & -160262 & -464244 & -551144 & -2593 & -12828 & -13959 \\
\hline Guatemala & -167032 & -394592 & -887952 & -2428 & -15339 & -32821 \\
\hline Honduras & -16874 & -105309 & -213623 & 0 & -4597 & -6908 \\
\hline Jamaica & -45627 & -134446 & -241391 & 0 & -240 & -3891 \\
\hline Mexico & -4431696 & -6244976 & -8503122 & -411448 & -482154 & -643209 \\
\hline Panama & -156098 & -194357 & -443949 & -18806 & -44237 & -93517 \\
\hline Paraguay & -102094 & -169375 & -334849 & -9501 & -15507 & -31764 \\
\hline Peru & -372698 & -1705813 & -3660546 & -25229 & -139723 & -237613 \\
\hline Dominican Republic & -169190 & -475766 & -951752 & -12452 & -31275 & -63441 \\
\hline Suriname & -13719 & -18425 & -27754 & -1600 & -2219 & -3096 \\
\hline Trinidad \& Tobago & -30051 & -29049 & -63984 & -1315 & -1252 & -5572 \\
\hline Uruguay & -174529 & -77208 & -177839 & -63398 & -32449 & -65516 \\
\hline LAC Average & -8933811 & -28943779 & -52240838 & -1060456 & -3674167 & -7278224 \\
\hline LA Average & -8837808 & -28751878 & -51893633 & -1056482 & -3668505 & -7262774 \\
\hline Caribbean Average & -96003 & -191900 & -347205 & -3975 & -5662 & -15450 \\
\hline
\end{tabular}

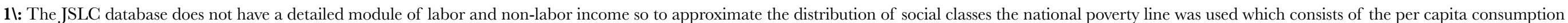

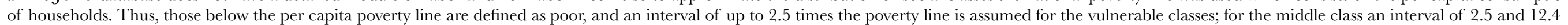

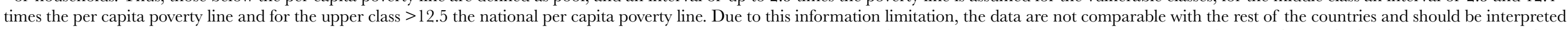

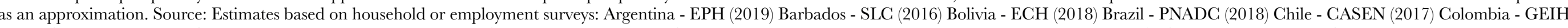

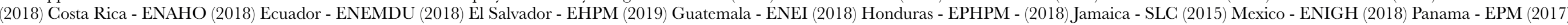
Paraguay - EPHC (2018) Peru - ENAHO (2018) Dominican Republic - ENCFT (2017) Suriname - SLC (2017) Trinidad and Tobago - CSSP (2015) Uruguay - ECH (2019). 
Table A.6. Poverty gap of the poor (extreme and moderate)

\begin{tabular}{|c|c|c|c|c|}
\hline \multirow{2}{*}{ Country } & \multicolumn{4}{|c|}{ Poverty gap of the poor (extreme and moderate) } \\
\hline & Base Scenario & Scenario A & Scenario B & Scenario $\mathrm{C}$ \\
\hline Argentina (urban) & 40.0 & 42.0 & 45.3 & 50.4 \\
\hline Barbados & 51.4 & 56.1 & 56.4 & 60.9 \\
\hline Bolivia & 44.4 & 45.0 & 50.7 & 57.2 \\
\hline Brazil & 41.5 & 42.2 & 49.5 & 57.4 \\
\hline Chile & 37.6 & 37.9 & 44.6 & 51.6 \\
\hline Colombia & 45.8 & 50.2 & 49.1 & 52.5 \\
\hline Costa Rica & 36.1 & 37.1 & 39.3 & 42.4 \\
\hline Ecuador & 38.1 & 39.5 & 46.7 & 54.2 \\
\hline El Salvador & 33.4 & 37.3 & 45.2 & 47.3 \\
\hline Guatemala & 46.1 & 49.5 & 51.8 & 57.2 \\
\hline Honduras & 50.2 & 51.1 & 52.8 & 55.4 \\
\hline Jamaica & 26.3 & 28.8 & 33.0 & 40.0 \\
\hline Mexico & 36.0 & 41.2 & 44.3 & 47.3 \\
\hline Panama & 41.0 & 44.9 & 48.8 & 56.5 \\
\hline Paraguay & 37.5 & 40.3 & 40.8 & 43.9 \\
\hline Peru & 35.0 & 36.6 & 42.4 & 50.0 \\
\hline Dominican Republic & 33.1 & 34.8 & 39.7 & 46.3 \\
\hline Suriname & 42.7 & 46.6 & 48.5 & 50.5 \\
\hline Trinidad and Tobago & 31.9 & 35.2 & 34.6 & 37.2 \\
\hline Uruguay & 29.2 & 38.5 & 33.9 & 38.7 \\
\hline LAC Average & 39.0 & 41.8 & 44.9 & 49.9 \\
\hline LA Average & 39.2 & 41.9 & 45.4 & 50.6 \\
\hline Caribbean Average & 38.1 & 41.7 & 43.1 & 47.1 \\
\hline
\end{tabular}

Source: Estimates based on household or employment surveys: Argentina - EPH (2019) Barbados - SLC (2016) Bolivia - ECH (2018) Brazil - PNADC (2018) Chile - CASEN (2017) Colombia - GEIH (2018) Costa Rica - ENAHO (2018) Ecuador ENEMDU (2018) El Salvador - EHPM (2019) Guatemala - ENEI (2018) Honduras - EPHPM - (2018) Jamaica - SLC (2015) Mexico - ENIGH (2018) Panama - EPM (2017) Paraguay - EPHC (2018) Peru - ENAHO (2018) Dominican Republic ENCFT (2017) Suriname - SLC (2017) Trinidad and Tobago - CSSP (2015) Uruguay - ECH (2019).

Table A.7. Percentage of households owning a home (owning or paying a mortgage)

\begin{tabular}{lcccc}
\hline \multicolumn{1}{c}{ Country } & \multicolumn{4}{c}{ Percentage of homes owned } \\
& Poor & Vulnerable & Middle class & High class \\
\hline Barbados & 64.5 & 68.6 & 70.5 & 82.8 \\
Bolivia & 80.1 & 60.9 & 57.8 & 66.7 \\
Brazil & 70.8 & 70.7 & 73.8 & 76.1 \\
Chile & 59.8 & 61.4 & 60.5 & 56.8 \\
Costa Rica & 64.1 & 69.4 & 73.8 & 76.8 \\
Ecuador & 69.0 & 59.0 & 57.0 & 58.0 \\
El Salvador & 63.6 & 60.5 & 64.2 & 68.1 \\
Honduras & 23.3 & 28.0 & 28.2 & 39.6 \\
Jamaica & 56.8 & 55.5 & 54.3 & 64.3
\end{tabular}


Table A.7 (continued) Percentage of households owning a home (owning or paying a mortgage)

\begin{tabular}{lcccc}
\hline \multicolumn{1}{c}{ Country } & \multicolumn{4}{c}{ Percentage of homes owned } \\
& Poor & Vulnerable & Middle class & High class \\
\hline Mexico & 71.5 & 67.5 & 67.4 & 65.2 \\
Panama & 87.1 & 81.1 & 79.3 & 76.8 \\
Paraguay & 85.5 & 79.3 & 72.8 & 72.4 \\
Peru & 77.9 & 68.5 & 67.8 & 65.7 \\
Dominican Republic & 54.8 & 54.0 & 49.7 & 62.7 \\
Suriname & 78.7 & 75.7 & 75.7 & 68.2 \\
Uruguay & 42.3 & 52.0 & 58.8 & 66.0 \\
\hline
\end{tabular}

Table A.8. Percentage of households with rental housing

\begin{tabular}{lrccc}
\hline \multicolumn{1}{c}{ Country } & \multicolumn{4}{c}{ Percentage of rental housing } \\
& Poor & Vulnerable & Middle class & High class \\
\hline Barbados & 20.4 & 19.2 & 16.6 & 12.9 \\
Bolivia & 6.7 & 15.5 & 19.2 & 20.5 \\
Brazil & 14.3 & 18.5 & 18.8 & 20.6 \\
Chile & 14.1 & 16.0 & 23.7 & 37.3 \\
Costa Rica & 16.5 & 17.8 & 19.2 & 21.3 \\
Ecuador & 13.0 & 19.0 & 22.0 & 24.0 \\
El Salvador & 6.1 & 12.6 & 16.6 & 14.5 \\
Honduras & 76.7 & 72.0 & 71.8 & 60.4 \\
Jamaica & 7.6 & 15.9 & 22.4 & 35.7 \\
Mexico & 8.3 & 14.3 & 19.4 & 28.1 \\
Panama & 5.4 & 10.5 & 14.6 & 20.6 \\
Paraguay & 2.5 & 7.8 & 17.7 & 21.6 \\
Peru & 4.3 & 8.5 & 12.7 & 21.0 \\
Dominican Republic & 26.7 & 29.6 & 35.6 & 28.3 \\
Suriname & 11.4 & 10.5 & 14.0 & 20.6 \\
Uruguay & 11.3 & 14.9 & 20.7 & 23.8 \\
\hline
\end{tabular}

Source: Estimates based on household or employment surveys: Argentina - EPH (2019) Barbados - SLC (2016) Bolivia - ECH (2018) Brazil - PNADC (2018) Chile - CASEN (2017) Colombia - GEIH (2018) Costa Rica - ENAHO (2018) Ecuador ENEMDU (2018) El Salvador - EHPM (2019) Guatemala - ENEI (2018) Honduras - EPHPM - (2018) Jamaica - SLC (2015) Mexico - ENIGH (2018) Panama - EPM (2017) Paraguay - EPHC (2018) Peru - ENAHO (2018) Dominican Republic ENCFT (2017) Suriname - SLC (2017) Trinidad and Tobago - CSSP (2015) Uruguay - ECH (2019). 
Table A.9. Sociodemographic profile of the population that moves from consolidated middle class to vulnerable middle class ( $\%)$ by country

\begin{tabular}{|c|c|c|c|c|c|c|c|c|c|c|c|c|c|c|}
\hline \multirow[b]{2}{*}{ Country } & \multirow[b]{2}{*}{$\begin{array}{l}0-15 \text { years } \\
\text { old }\end{array}$} & \multirow[b]{2}{*}{$\begin{array}{c}16-24 \\
\text { years old }\end{array}$} & \multicolumn{3}{|l|}{ Age } & \multicolumn{2}{|c|}{ Sex } & \multicolumn{2}{|c|}{ Area } & \multicolumn{5}{|c|}{ Educational level of people of $25+$} \\
\hline & & & $\begin{array}{c}25-44 \\
\text { years old }\end{array}$ & $\begin{array}{c}45-64 \\
\text { years old }\end{array}$ & $\begin{array}{l}65 \text { or } \\
\text { more }\end{array}$ & Woman & Man & Urban & Rural & $\begin{array}{l}\text { Incomplete } \\
\text { Primary }\end{array}$ & $\begin{array}{l}\text { Complete } \\
\text { Primary }\end{array}$ & $\begin{array}{c}\text { Low } \\
\text { Secondary }\end{array}$ & $\begin{array}{l}\text { Upper- Sec- } \\
\text { ondary }\end{array}$ & Tertiary \\
\hline Argentina (urban) $1 \backslash$ & 18.0 & 13.6 & 25.1 & 19.6 & 23.7 & 52.9 & 47.1 & - & - & 7.3 & 25.8 & 13.0 & 29.6 & 22.8 \\
\hline Barbados $2 \backslash$ & 15.5 & 8.6 & 25.4 & 29.8 & 20.1 & 52.5 & 47.5 & - & - & - & 24.8 & - & 39.2 & 27.9 \\
\hline Bolivia & 26.4 & 17.2 & 29.1 & 19.0 & 8.3 & 51.4 & 48.6 & 87.0 & 13.0 & 27.1 & 3.2 & 9.5 & 29.9 & 30.3 \\
\hline Brazil & 14.2 & 12.5 & 26.9 & 25.4 & 20.9 & 52.1 & 47.9 & 88.2 & 11.8 & 38.2 & 5.9 & 14.1 & 29.3 & 12.4 \\
\hline Chile & 19.9 & 14.6 & 24.1 & 25.4 & 15.9 & 53.3 & 46.7 & 87.4 & 12.6 & 25.2 & 10.5 & 10.1 & 35.2 & 18.8 \\
\hline Colombia & 23.4 & 17.0 & 28.8 & 22.2 & 8.5 & 49.7 & 50.3 & 81.0 & 19.0 & 19.8 & 16.4 & 11.1 & 29.6 & 18.3 \\
\hline Costa Rica & 21.1 & 16.2 & 28.9 & 22.8 & 11.0 & 51.5 & 48.5 & 73.4 & 26.6 & 18.3 & 33.9 & 16.9 & 18.9 & 11.5 \\
\hline Ecuador & 26.4 & 16.5 & 27.0 & 20.0 & 10.0 & 50.9 & 49.1 & 77.8 & 22.2 & 19.2 & 27.3 & 9.1 & 3.8 & 26.0 \\
\hline El Salvador & 17.2 & 20.2 & 29.8 & 22.8 & 10.1 & 52.1 & 47.9 & 76.0 & 24.0 & 28.9 & 10.3 & 17.3 & 26.7 & 16.8 \\
\hline Guatemala & 20.9 & 22.3 & 31.0 & 18.8 & 6.9 & 50.5 & 49.5 & 64.1 & 35.9 & 25.2 & 17.6 & 14.8 & 14.6 & 27.9 \\
\hline Honduras & 22.1 & 21.4 & 27.0 & 21.6 & 7.9 & 53.6 & 46.4 & 81.3 & 18.7 & 20.8 & 24.7 & 11.9 & 21.7 & 20.4 \\
\hline Jamaica3\ & 16.7 & 15.6 & 25.5 & 26.8 & 15.4 & 52.8 & 47.2 & 51.3 & 48.7 & - & - & - & - & - \\
\hline Mexico & 21.4 & 17.6 & 28.8 & 23.7 & 8.5 & 50.5 & 49.5 & 86.7 & 13.3 & 13.9 & 14.0 & 27.3 & 47.0 & 21.9 \\
\hline Panama & 26.4 & 18.0 & 24.2 & 20.7 & 10.8 & 50.9 & 49.1 & 77.3 & 22.7 & 11.7 & 21.0 & 18.9 & 32.2 & 16.2 \\
\hline Paraguay & 30.7 & 19.5 & 28.8 & 15.1 & 6.0 & 50.0 & 50.0 & 70.4 & 29.6 & 22.2 & 19.5 & 16.4 & 22.9 & 19.0 \\
\hline Peru & 22.2 & 16.2 & 26.7 & 24.0 & 10.9 & 50.9 & 49.1 & 93.2 & 6.8 & 14.5 & 10.7 & 9.5 & 34.9 & 29.6 \\
\hline Dominican Republic & 22.4 & 17.5 & 28.9 & 21.9 & 9.3 & 49.9 & 50.1 & 83.1 & 16.9 & 36.9 & 11.9 & 9.3 & 25.1 & 16.7 \\
\hline Suriname & 26.0 & 16.0 & 26.2 & 23.0 & 8.8 & 53.2 & 46.8 & 96.1 & 3.9 & 26.8 & 6.9 & 18.8 & 33.5 & 10.7 \\
\hline Trinidad and Tobago4\ & 20.9 & 16.7 & 31.1 & 23.5 & 7.8 & 49.3 & 50.7 & - & - & - & - & - & - & - \\
\hline Uruguay & 23.1 & 15.8 & 24.0 & 20.6 & 16.4 & 53.1 & 46.9 & 78.2 & 21.8 & 14.8 & 30.7 & 26.1 & 20.2 & 8.3 \\
\hline
\end{tabular}

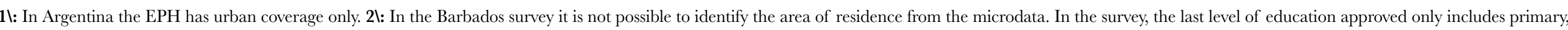
secondary, and higher education, so it is not possible to determine the years of education to construct the disaggregated educational categories. 31: In the survey Jamaica, the years of education for the working-age population cannot be constructed. 4: In the Trinidad and Tobago survey it is not possible to identify the area of residence from the microdata, nor the years of education for the working-age population 
Table A.10. Sociodemographic profile of the population moving from vulnerable to poor middle class (extreme and moderate) by country

\begin{tabular}{|c|c|c|c|c|c|c|c|c|c|c|c|c|c|c|}
\hline \multirow[b]{2}{*}{ Country } & \multirow[b]{2}{*}{$\begin{array}{c}0-15 \\
\text { years old }\end{array}$} & \multirow[b]{2}{*}{$\begin{array}{c}16-24 \\
\text { years old }\end{array}$} & \multicolumn{2}{|l|}{ Age } & \multirow[b]{2}{*}{$\begin{array}{l}65 \text { o } \\
\text { more }\end{array}$} & \multicolumn{2}{|c|}{ Sex } & \multicolumn{2}{|c|}{ Area } & \multicolumn{5}{|c|}{ Educational level of people of $25+$} \\
\hline & & & $\begin{array}{c}25-44 \\
\text { years old }\end{array}$ & $\begin{array}{c}45-64 \\
\text { years old }\end{array}$ & & Woman & Man & Urban & Rural & $\begin{array}{l}\text { Incomplete } \\
\text { Primary }\end{array}$ & $\begin{array}{c}\text { Complete } \\
\text { Primary }\end{array}$ & $\begin{array}{c}\text { Low } \\
\text { Secondary }\end{array}$ & $\begin{array}{c}\text { Upper- } \\
\text { Secondary }\end{array}$ & Tertiary \\
\hline Argentina (urban) $1 \backslash$ & 35.2 & 17.2 & 27.5 & 14.3 & 5.8 & 53.5 & 46.5 & - & - & 9.3 & 26.2 & 15.0 & 31.7 & 15.8 \\
\hline Barbados $2 \backslash$ & 25.2 & 14.1 & 25.8 & 20.5 & 14.4 & 60.0 & 40.0 & - & - & - & 26.9 & - & 42.7 & 21.4 \\
\hline Bolivia & 39.0 & 16.4 & 25.3 & 12.6 & 6.8 & 52.4 & 47.6 & 65.2 & 34.8 & 42.1 & 5.0 & 10.9 & 30.0 & 11.9 \\
\hline Brazil & 32.7 & 17.3 & 30.4 & 15.9 & 3.7 & 52.3 & 47.7 & 81.9 & 18.1 & 32.8 & 7.4 & 20.1 & 33.3 & 6.4 \\
\hline Chile & 31.2 & 16.0 & 24.7 & 18.7 & 9.4 & 53.7 & 46.3 & 78.6 & 21.4 & 28.7 & 13.6 & 10.9 & 33.4 & 13.0 \\
\hline Colombia & 34.6 & 16.8 & 26.0 & 16.2 & 6.5 & 50.7 & 49.3 & 67.5 & 32.5 & 30.4 & 19.1 & 11.8 & 23.9 & 9.6 \\
\hline Costa Rica & 34.5 & 15.3 & 25.6 & 18.1 & 6.5 & 53.4 & 46.6 & 52.0 & 48.0 & 30.5 & 37.8 & 15.4 & 12.7 & 3.6 \\
\hline Ecuador & 36.0 & 16.5 & 25.0 & 14.2 & 8.3 & 50.9 & 49.1 & 60.1 & 39.9 & 33.3 & 33.9 & 10.3 & 4.2 & 7.4 \\
\hline El Salvador & 29.9 & 19.6 & 27.1 & 15.1 & 8.4 & 55.4 & 44.6 & 50.5 & 49.5 & 49.7 & 10.1 & 18.4 & 18.6 & 3.3 \\
\hline Guatemala & 35.1 & 19.7 & 27.6 & 12.6 & 5.0 & 51.4 & 48.6 & 47.6 & 52.4 & 50.5 & 18.5 & 13.0 & 7.2 & 10.9 \\
\hline Honduras & 34.9 & 17.7 & 28.2 & 13.4 & 5.7 & 49.3 & 50.7 & 63.1 & 36.9 & 30.0 & 32.4 & 9.3 & 20.7 & 6.8 \\
\hline Jamaica3\ & 29.3 & 16.8 & 24.8 & 17.4 & 11.7 & 54.6 & 45.4 & 40.6 & 59.4 & - & - & - & - & - \\
\hline Mexico & 33.3 & 15.9 & 27.3 & 15.7 & 7.9 & 52.4 & 47.6 & 71.4 & 28.6 & 24.9 & 19.5 & 32.8 & 45.9 & 6.2 \\
\hline Panama & 40.0 & 13.3 & 21.7 & 13.8 & 11.3 & 50.3 & 49.7 & 48.5 & 51.5 & 28.5 & 30.3 & 17.8 & 18.3 & 5.1 \\
\hline Paraguay & 38.9 & 15.2 & 23.7 & 14.7 & 7.6 & 49.3 & 50.7 & 45.4 & 54.6 & 41.3 & 24.2 & 12.4 & 15.7 & 6.4 \\
\hline Peru & 34.0 & 14.0 & 23.8 & 17.4 & 10.8 & 52.7 & 47.3 & 68.4 & 31.6 & 33.0 & 16.8 & 9.9 & 29.6 & 9.2 \\
\hline Dominican Republic & 36.5 & 16.7 & 25.2 & 13.9 & 7.8 & 53.5 & 46.5 & 74.7 & 25.3 & 48.2 & 12.2 & 10.6 & 19.3 & 9.6 \\
\hline Suriname & 28.1 & 23.5 & 23.2 & 20.5 & 4.3 & 49.4 & 50.6 & 98.2 & 1.8 & 21.8 & 12.4 & 36.3 & 24.9 & 3.7 \\
\hline Trinidad and Tobago4\ & 45.3 & 9.7 & 27.0 & 14.0 & 4.0 & 56.7 & 43.3 & - & - & - & - & - & - & - \\
\hline Uruguay & 44.5 & 18.5 & 22.4 & 11.8 & 2.7 & 53.1 & 46.9 & 81.6 & 18.4 & 15.1 & 41.1 & 26.5 & 11.8 & 5.4 \\
\hline
\end{tabular}


secondary and higher education, so it is not possible to determine the years of education to construct the disaggregated educational categories. 31: In the survey Jamaica, the years of education for the working-age population cannot be constructed. 4: In the Trinidad and Tobago survey it is not possible to identify the area of residence from the microdata, nor the years of education for the working-age population. 
Table A.11. Results of the simulation of interventions to cushion impacts on the distribution of social classes

\begin{tabular}{|c|c|c|c|c|c|c|c|c|c|c|}
\hline \multirow[b]{2}{*}{ Country } & \multicolumn{5}{|c|}{ P1: Unemployment insurance } & \multicolumn{5}{|c|}{ P2: Support for self-employed ${ }^{2}$} \\
\hline & $\begin{array}{l}\text { Extreme } \\
\text { poor }\end{array}$ & $\begin{array}{l}\text { Moderate } \\
\text { poor }\end{array}$ & $\begin{array}{l}\text { Vulnerable mid- } \\
\text { dle-class }\end{array}$ & $\begin{array}{l}\text { Consolidated } \\
\text { middle-class }\end{array}$ & Rich & $\begin{array}{l}\text { Extreme } \\
\text { poor }\end{array}$ & $\begin{array}{l}\text { Moderate } \\
\text { poor }\end{array}$ & $\begin{array}{l}\text { Vulnerable mid- } \\
\text { dle-class }\end{array}$ & $\begin{array}{l}\text { Consolidated } \\
\text { middle-class }\end{array}$ & Rich \\
\hline Argentina (urban) $1 \backslash$ & 10.1 & 12.2 & 42.6 & 33.9 & 1.2 & 10.0 & 11.5 & 42.1 & 35.2 & 1.2 \\
\hline Barbados $2 \backslash$ & 16.1 & 13.2 & 36.6 & 32.8 & 1.3 & 18.6 & 11.4 & 35.5 & 33.2 & 1.3 \\
\hline Bolivia & 19.5 & 15.5 & 42.0 & 22.8 & 0.2 & 12.3 & 15.2 & 46.4 & 25.9 & 0.2 \\
\hline Brazil & 14.1 & 12.4 & 39.0 & 31.1 & 3.4 & 12.1 & 11.9 & 39.4 & 33.2 & 3.4 \\
\hline Chile & 4.1 & 7.7 & 43.5 & 40.4 & 4.3 & 3.8 & 7.3 & 42.6 & 41.9 & 4.4 \\
\hline Colombia & 16.6 & 14.1 & 34.5 & 31.1 & 3.7 & 11.5 & 12.2 & 38.4 & 34.1 & 3.7 \\
\hline Costa Rica & 7.4 & 9.8 & 37.5 & 41.0 & 4.3 & 6.3 & 9.4 & 37.9 & 42.2 & 4.3 \\
\hline Ecuador & 17.7 & 16.5 & 40.9 & 24.0 & 0.9 & 11.6 & 16.0 & 43.8 & 27.5 & 1.1 \\
\hline El Salvador & 17.6 & 21.6 & 46.0 & 14.5 & 0.2 & 13.2 & 20.9 & 49.4 & 16.3 & 0.2 \\
\hline Guatemala & 40.7 & 20.7 & 28.7 & 9.9 & 0.1 & 33.6 & 22.7 & 32.7 & 10.9 & 0.2 \\
\hline Honduras & 38.0 & 19.4 & 30.5 & 11.7 & 0.4 & 34.9 & 20.9 & 31.8 & 12.0 & 0.4 \\
\hline Mexico & 19.9 & 23.8 & 41.2 & 14.7 & 0.2 & 17.5 & 23.8 & 43.0 & 15.4 & 0.2 \\
\hline Panama & 12.6 & 10.5 & 36.0 & 37.9 & 3.0 & 8.8 & 10.6 & 37.4 & 40.1 & 3.0 \\
\hline Paraguay & 10.1 & 11.3 & 39.5 & 36.6 & 2.5 & 6.2 & 11.0 & 41.5 & 38.7 & 2.5 \\
\hline Peru & 14.5 & 15.8 & 44.8 & 24.0 & 0.9 & 7.4 & 14.4 & 49.8 & 27.6 & 0.9 \\
\hline Dominican Republic & 10.7 & 15.6 & 47.7 & 25.2 & 0.8 & 8.1 & 13.6 & 48.8 & 28.7 & 0.9 \\
\hline Suriname & 12.9 & 11.0 & 39.4 & 35.1 & 1.6 & 12.2 & 12.0 & 38.8 & 35.4 & 1.6 \\
\hline Trinidad and Tobago & 5.3 & 7.5 & 42.1 & 44.0 & 1.0 & 4.4 & 7.1 & 41.8 & 45.8 & 1.0 \\
\hline Uruguay & 1.3 & 3.7 & 29.5 & 61.8 & 3.7 & 1.1 & 3.3 & 28.9 & 62.9 & 3.8 \\
\hline
\end{tabular}


Table A.11 (continued) Results of the simulation of interventions to cushion impacts on the distribution of social classes

\begin{tabular}{|c|c|c|c|c|c|c|c|c|c|c|}
\hline \multirow[b]{2}{*}{ Country } & \multicolumn{5}{|c|}{ P3: Doubling Support for Social Programs ${ }^{3 \backslash}$} & \multicolumn{5}{|c|}{ P4: Rescheduling Tax and Social Security Contribution Payments ${ }^{4}$} \\
\hline & $\begin{array}{l}\text { Extreme } \\
\text { poor }\end{array}$ & $\begin{array}{l}\text { Moderate } \\
\text { poor }\end{array}$ & $\begin{array}{l}\text { Vulnerable mid- } \\
\text { dle-class }\end{array}$ & $\begin{array}{c}\text { Consolidated } \\
\text { middle-class }\end{array}$ & Rich & $\begin{array}{l}\text { Extreme } \\
\text { poor }\end{array}$ & $\begin{array}{l}\text { Moderate } \\
\text { poor }\end{array}$ & $\begin{array}{l}\text { Vulnerable mid- } \\
\text { dle-class }\end{array}$ & $\begin{array}{l}\text { Consolidated } \\
\text { middle-class }\end{array}$ & Rich \\
\hline Argentina (urban) $1 \backslash$ & 9.5 & 11.6 & 43.9 & 33.8 & 1.2 & 11.8 & 11.1 & 38.1 & 37.3 & 1.7 \\
\hline Barbados $2 \backslash$ & 19.1 & 11.6 & 34.9 & 33.1 & 1.3 & 20.1 & 10.7 & 34.4 & 32.9 & 1.9 \\
\hline Bolivia & 17.0 & 15.7 & 43.5 & 23.6 & 0.2 & 19.5 & 14.8 & 39.7 & 25.6 & 0.4 \\
\hline Brazil & 12.1 & 12.6 & 39.8 & 32.1 & 3.4 & 13.1 & 10.2 & 34.8 & 36.9 & 5.0 \\
\hline Chile & 4.6 & 8.0 & 43.2 & 39.9 & 4.3 & 4.4 & 6.4 & 36.8 & 46.4 & 6.0 \\
\hline Colombia & 16.2 & 14.2 & 34.9 & 30.9 & 3.7 & 17.3 & 13.6 & 32.4 & 32.4 & 4.3 \\
\hline Costa Rica & 7.6 & 9.5 & 37.1 & 41.4 & 4.3 & 7.5 & 8.7 & 35.6 & 43.2 & 5.0 \\
\hline Ecuador & 15.9 & 16.2 & 42.5 & 24.5 & 0.9 & 16.6 & 14.3 & 38.1 & 29.3 & 1.7 \\
\hline El Salvador & 18.4 & 21.7 & 45.3 & 14.5 & 0.2 & 17.8 & 19.4 & 44.2 & 18.3 & 0.3 \\
\hline Guatemala & 40.7 & 20.7 & 28.5 & 9.8 & 0.1 & 40.5 & 18.4 & 28.3 & 12.5 & 0.2 \\
\hline Honduras & 38.8 & 19.5 & 29.9 & 11.4 & 0.4 & 39.2 & 18.0 & 30.0 & 12.3 & 0.5 \\
\hline Mexico & 19.0 & 24.2 & 41.8 & 14.7 & 0.2 & 20.0 & 22.0 & 39.3 & 17.4 & 0.6 \\
\hline Panama & 11.2 & 10.2 & 36.8 & 38.9 & 3.0 & 12.1 & 9.3 & 30.5 & 43.7 & 4.4 \\
\hline Paraguay & 9.5 & 11.4 & 39.9 & 36.7 & 2.5 & 11.0 & 11.4 & 37.8 & 37.2 & 2.7 \\
\hline Peru & 13.0 & 16.3 & 46.0 & 23.8 & 0.9 & 15.0 & 15.2 & 41.2 & 27.3 & 1.2 \\
\hline Dominican Republic & 9.8 & 15.3 & 48.5 & 25.5 & 0.8 & 10.3 & 13.8 & 46.3 & 28.5 & 1.2 \\
\hline Suriname & 12.6 & 11.6 & 38.8 & 35.3 & 1.6 & 14.1 & 10.8 & 36.3 & 36.9 & 1.9 \\
\hline Trinidad and Tobago & 3.1 & 9.1 & 43.0 & 43.8 & 1.0 & n.d. & n.d. & n.d. & n.d. & n.d. \\
\hline Uruguay & 1.1 & 3.3 & 30.6 & 61.3 & 3.7 & 1.8 & 3.8 & 26.0 & 63.3 & 5.1 \\
\hline
\end{tabular}

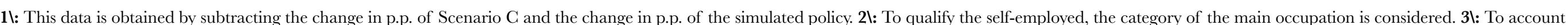

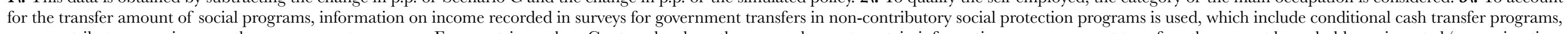

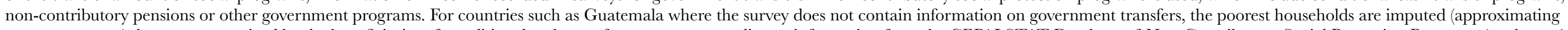

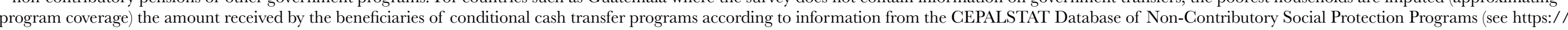

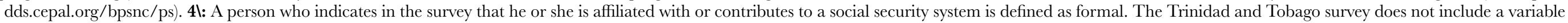

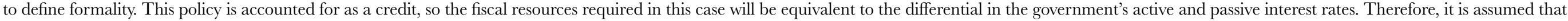
if both are equivalent and the administrative cost is charged at the lending rate, there will be no fiscal cost.

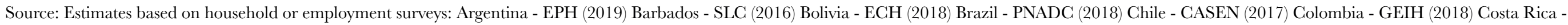

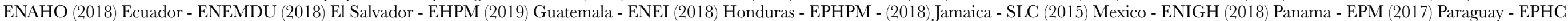
(2018) Peru - ENAHO (2018) Dominican Republic - ENCFT (2017) Suriname - SLG (2017) Trinidad and Tobago - CSSP (2015) Uruguay - ECH (2019). 
Table A.12. Results of the simulation of interventions to cushion impacts on the distribution of social classes (in p.p.)

\begin{tabular}{|c|c|c|c|c|c|c|c|c|c|c|}
\hline \multirow[b]{2}{*}{ Country } & \multicolumn{5}{|c|}{ P1: Unemployment insurance } & \multicolumn{5}{|c|}{ P2: Support for self-employed ${ }^{2 \}$} \\
\hline & $\begin{array}{l}\text { Extreme } \\
\text { poor }\end{array}$ & $\begin{array}{l}\text { Moderate } \\
\text { poor }\end{array}$ & $\begin{array}{l}\text { Vulnerable mid- } \\
\text { dle-class }\end{array}$ & $\begin{array}{l}\text { Consolidated } \\
\text { middle-class }\end{array}$ & Rich & $\begin{array}{l}\text { Extreme } \\
\text { poor }\end{array}$ & Moderate poor & $\begin{array}{l}\text { Vulnerable mid- } \\
\text { dle-class }\end{array}$ & $\begin{array}{l}\text { Consolidated } \\
\text { middle-class }\end{array}$ & Rich \\
\hline Argentina (urban) & 1.0 & 2.7 & 5.7 & -8.5 & -0.9 & 0.9 & 1.9 & 5.2 & -7.2 & -0.9 \\
\hline Barbados & -0.7 & 3.4 & 4.6 & -5.9 & -1.4 & 1.8 & 1.6 & 3.4 & -5.5 & -1.3 \\
\hline Bolivia & 5.2 & 3.9 & 0.9 & -9.7 & -0.4 & -2.0 & 3.6 & 5.3 & -6.6 & -0.3 \\
\hline Brazil & 4.5 & 3.1 & 7.4 & -12.7 & -2.3 & 2.5 & 2.6 & 7.7 & -10.5 & -2.3 \\
\hline Chile & 1.0 & 3.1 & 9.1 & -11.1 & -2.1 & 0.7 & 2.8 & 8.2 & -9.6 & -2.1 \\
\hline Colombia & 2.0 & 1.7 & 0.7 & -3.5 & -0.8 & -3.1 & -0.2 & 4.6 & -0.5 & -0.8 \\
\hline Costa Rica & 1.1 & 1.3 & 2.0 & -3.4 & -0.9 & -0.1 & 0.9 & 2.3 & -2.2 & -0.9 \\
\hline Ecuador & 7.0 & 4.5 & 1.2 & -11.6 & -1.1 & 1.0 & 3.9 & 4.1 & -8.1 & -1.0 \\
\hline El Salvador & 5.9 & 4.9 & -2.6 & -8.0 & -0.2 & 1.5 & 4.2 & 0.8 & -6.3 & -0.2 \\
\hline Guatemala & 9.2 & 0.5 & -4.5 & -5.0 & -0.2 & 2.1 & 2.5 & -0.4 & -4.0 & -0.2 \\
\hline Honduras & 2.0 & 0.9 & -0.7 & -2.0 & -0.1 & -1.2 & 2.4 & 0.5 & -1.7 & -0.1 \\
\hline Mexico & 4.1 & 3.8 & -0.9 & -6.5 & -0.5 & 1.6 & 3.8 & 0.9 & -5.8 & -0.5 \\
\hline Panama & 4.5 & 2.9 & 5.6 & -10.7 & -2.3 & 0.7 & 3.1 & 7.0 & -8.5 & -2.2 \\
\hline Paraguay & 0.9 & 1.0 & 2.7 & -4.1 & -0.5 & -3.0 & 0.7 & 4.7 & -2.0 & -0.4 \\
\hline Peru & 5.4 & 3.8 & 2.1 & -10.7 & -0.7 & -1.8 & 2.4 & 7.2 & -7.0 & -0.7 \\
\hline Dominican Republic & 4.2 & 4.2 & 1.3 & -9.0 & -0.6 & 1.6 & 2.2 & 2.3 & -5.5 & -0.6 \\
\hline Suriname & 0.5 & 2.2 & 2.9 & -5.0 & -0.6 & -0.2 & 3.2 & 2.3 & -4.7 & -0.6 \\
\hline Trinidad and Tobago & 1.3 & -0.3 & 3.9 & -4.4 & -0.4 & 0.4 & -0.8 & 3.5 & -2.7 & -0.4 \\
\hline Uruguay & 0.0 & 0.8 & 4.9 & -3.9 & -1.8 & -0.2 & 0.4 & 4.3 & -2.8 & -1.8 \\
\hline
\end{tabular}


Table A.12 (continued) Results of the simulation of interventions to cushion impacts on the distribution of social classes (in p.p.)

\begin{tabular}{|c|c|c|c|c|c|c|c|c|c|c|}
\hline \multirow[b]{2}{*}{ Country } & \multicolumn{5}{|c|}{ P3: Doubling Support for Social Programs ${ }^{3 \backslash}$} & \multicolumn{5}{|c|}{ P4: Rescheduling Tax and Social Security Contribution Payments ${ }^{4}$} \\
\hline & $\begin{array}{l}\text { Extreme } \\
\text { poor }\end{array}$ & $\begin{array}{l}\text { Moderate } \\
\text { poor }\end{array}$ & $\begin{array}{l}\text { Vulnerable mid- } \\
\text { dle-class }\end{array}$ & $\begin{array}{l}\text { Consolidated } \\
\text { middle-class }\end{array}$ & Rich & $\begin{array}{l}\text { Extreme } \\
\text { poor }\end{array}$ & $\begin{array}{l}\text { Moderate } \\
\text { poor }\end{array}$ & $\begin{array}{l}\text { Vulnerable mid- } \\
\text { dle-class }\end{array}$ & $\begin{array}{l}\text { Consolidated } \\
\text { middle-class }\end{array}$ & Rich \\
\hline Argentina (urban) & 0.4 & 2.1 & 7.0 & -8.6 & -0.9 & 2.6 & 1.6 & 1.2 & -5.0 & -0.4 \\
\hline Barbados & 2.3 & 1.8 & 2.9 & -5.6 & -1.4 & 3.3 & 0.9 & 2.3 & -5.8 & -0.8 \\
\hline Bolivia & 2.7 & 4.2 & 2.4 & -8.9 & -0.3 & 5.2 & 3.3 & -1.4 & -6.9 & -0.2 \\
\hline Brazil & 2.5 & 3.3 & 8.2 & -11.7 & -2.3 & 3.5 & 0.9 & 3.2 & -6.8 & -0.7 \\
\hline Chile & 1.5 & 3.4 & 8.8 & -11.6 & -2.2 & 1.3 & 1.9 & 2.4 & -5.1 & -0.5 \\
\hline Colombia & 1.6 & 1.8 & 1.1 & -3.7 & -0.8 & 2.7 & 1.2 & -1.4 & -2.2 & -0.2 \\
\hline Costa Rica & 1.3 & 1.1 & 1.6 & -3.0 & -0.9 & 1.1 & 0.3 & 0.1 & -1.2 & -0.2 \\
\hline Ecuador & 5.3 & 4.2 & 2.8 & -11.1 & -1.1 & 6.0 & 2.2 & -1.6 & -6.3 & -0.3 \\
\hline El Salvador & 6.6 & 4.9 & -3.3 & -8.1 & -0.2 & 6.1 & 2.6 & -4.4 & -4.2 & -0.1 \\
\hline Guatemala & 9.3 & 0.6 & -4.6 & -5.1 & -0.2 & 9.1 & -1.8 & -4.8 & -2.4 & -0.1 \\
\hline Honduras & 2.7 & 1.0 & -1.3 & -2.3 & -0.1 & 3.2 & -0.5 & -1.2 & -1.4 & 0.0 \\
\hline Mexico & 3.2 & 4.2 & -0.4 & -6.5 & -0.5 & 4.2 & 2.1 & -2.9 & -3.8 & -0.1 \\
\hline Panama & 3.0 & 2.6 & 6.4 & -9.7 & -2.3 & 4.0 & 1.7 & 0.1 & -4.9 & -0.8 \\
\hline Paraguay & 0.3 & 1.1 & 3.1 & -4.0 & -0.5 & 1.8 & 1.1 & 1.0 & -3.5 & -0.3 \\
\hline Peru & 3.8 & 4.3 & 3.4 & -10.8 & -0.7 & 5.8 & 3.2 & -1.4 & -7.3 & -0.4 \\
\hline Dominican Republic & 3.3 & 3.9 & 2.1 & -8.7 & -0.6 & 3.8 & 2.4 & -0.2 & -5.7 & -0.3 \\
\hline Suriname & 0.2 & 2.8 & 2.3 & -4.8 & -0.6 & 1.7 & 2.0 & -0.2 & -3.2 & -0.3 \\
\hline Trinidad and Tobago & -0.9 & 1.3 & 4.7 & -4.7 & -0.4 & n.d. & n.d. & n.d. & n.d. & 0.0 \\
\hline Uruguay & -0.2 & 0.4 & 6.0 & -4.4 & -1.9 & 0.5 & 1.0 & 1.4 & -2.4 & -0.5 \\
\hline
\end{tabular}

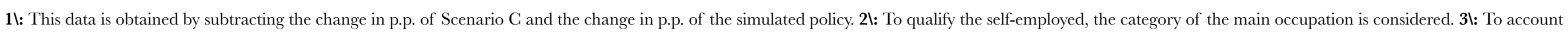



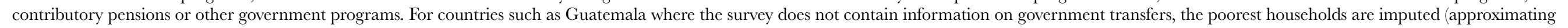

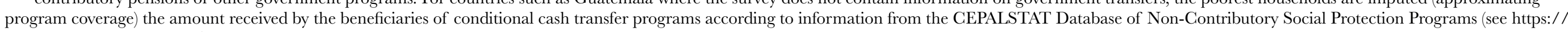

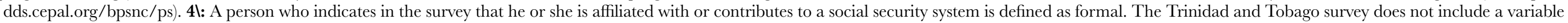


if both are equivalent and the administrative cost is charged at the lending rate, there will be no fiscal cost.



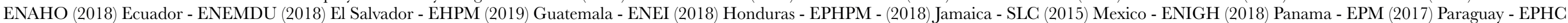
(2018) Peru - ENAHO (2018) Dominican Republic - ENCFT (2017) Suriname - SLC (2017) Trinidad and Tobago - CSSP (2015) Uruguay - ECH (2019). 
Table A.13. Results of estimates in percentage point changes in poverty under various methodologies

\begin{tabular}{|c|c|c|c|c|c|}
\hline \multirow{2}{*}{ Country } & \multicolumn{3}{|c|}{ Scenarios } & \multirow{2}{*}{ GEPAL (2020b) } & \multirow{2}{*}{$\underline{\text { IDB }(2020 \circ}$} \\
\hline & $\mathrm{A}$ & B & G & & \\
\hline Argentina (urban) & 1.4 & 2.6 & 5.8 & 10.8 & \\
\hline Bolivia & 0.4 & 3.9 & 9.9 & 3.8 & \\
\hline Brazil & 0.3 & 3.7 & 8.2 & 7.7 & \\
\hline Chile & 0.1 & 2.2 & 5.5 & 5.7 & \\
\hline Colombia & 3.2 & 1.9 & 4.5 & 5.1 & \\
\hline Costa Rica & 0.3 & 1.2 & 2.8 & 4.0 & 4.9 \\
\hline Ecuador & 1.7 & 5.9 & 11.7 & 7.0 & \\
\hline El Salvador & 2.5 & 10.0 & 12.2 & 6.5 & 7.4 \\
\hline Guatemala & 2.4 & 4.4 & 9.9 & 3.0 & 3.5 \\
\hline Honduras & 0.5 & 2.1 & 4.2 & 4.2 & 5.5 \\
\hline Mexico & 4.1 & 6.1 & 8.8 & 7.6 & 8.1 \\
\hline Panama & 2.3 & 3.2 & 7.6 & 2.9 & 7.1 \\
\hline Paraguay & 1.4 & 1.5 & 3.1 & 1.5 & \\
\hline Peru & 0.9 & 4.1 & 10.1 & 9.3 & \\
\hline República Dominicana & 0.8 & 3.9 & 8.9 & 4.4 & 6.3 \\
\hline Uruguay & 1.8 & 0.9 & 1.9 & 2.4 & \\
\hline Latin America & 1.5 & 3.6 & 7.2 & 7.1 & \\
\hline
\end{tabular}

